\title{
ADVANCES IN THE ANALYSIS OF HOUSEHOLDS IN THE EARLY \\ NEOLITHIC GROUPS OF THE IBERIAN PENINSULA: DECIPHERING A \\ PARTIAL ARCHAEOLOGICAL RECORD
}

Francisco Javier Jover Maestre

Universidad de Alicante (Alicante, Spain)

Instituto Universitario de Arqueología y Patrimonio Histórico (INAPH). Universidad de

Alicante. Carretera San Vicente del Raspeig, s/n, 03690 Sant Vicent del Raspeig,

Alicante, Spain

Email: javier.jover@ua.es

María Pastor Quiles

Universidad de Alicante (Alicante, Spain)

Email: m.pastor@ua.es

Palmira Torregrosa Giménez

Universidad de Alicante (Alicante, Spain)

Email: palmira.torregrosa@ua.es 


\begin{abstract}
In this paper, we analyze the data related to the households of the first farmers in the Iberian Peninsula during the early Neolithic and discuss the theoretical and archaeological constraints on their recognition. Information is limited by different factors, such as the traditional excavation exclusively of caves and the difficulties in preserving the archaeological record at open-air sites. Most of these sites present diverse types of structures, from production-consumption, storage or waste areas, to different types of possible dwellings. We argue that the most common type of settlement within these groups were farms, which would constitute basic units of productive and social organization. Lastly, we highlight the research approach involving the open-air excavation at settlements large enough to allow the identification of domestic units.
\end{abstract}

Keywords: Early Neolithic, First farmers, Iberian Peninsula, Household, Domestic Unit, Activity area, Open-air site, Social Iberoamerican Archaeology 


\section{Introduction}

Some 40 years ago the first archaeological studies analyzed households (Flannery and Winter 1976). The theoretical definition of the household quickly spread, to become a central unit of observation and analysis (Wilk and Rathje 1982; Wilk and McC. Netting 1984; Manzanilla 1986; Banning and Byrd 1987; Blanton 1994; Beaudry 2015; e.g.), to the extent that, a few years ago, it was considered to be "at the heart of archaeology" (Hendon 2007: 272). Since then, archaeological studies of the household, also called domestic unit, have increased considerably in number, its history and development being subject to analysis in multiple periods and cultures (Allison 1999; Hendon 2007; Flores 2007; Nash 2009; Carballo 2011; Yasur-Landau et al. 2011; Kadowak 2012; Douglass and Gonlin 2012; Castro et al. 2013; Madella et al. 2013; Beaudry 2015; e.g.). In addition, the archaeological study of Neolithic households in the Western Mediterranean also started to develop several decades ago (Ammerman et al. 1988). To date, the archaeological record related to Neolithic households has been increasingly analyzed (Frère-Sautot 2003; Robb 2007; Cavulli 2008; Pessina and Tiné 2008; Souvatzi 2007; 2008; Beeching and Sénépart 2009, Molist and Clop 2009; Rojo et al. 2010; Perrin et al. 2011; 2014; e.g.).

However, scarce information on the households of the Neolithic groups in the Iberian Peninsula is available (Puche and Díez 2003; Jover 2013; Alonso-Fernández 2017), mainly for two reasons: firstly, the perpetuation of research focusing primarily on cave sites; and secondly, the limited excavation area in open-air sites, which have only a partial archaeological record. 


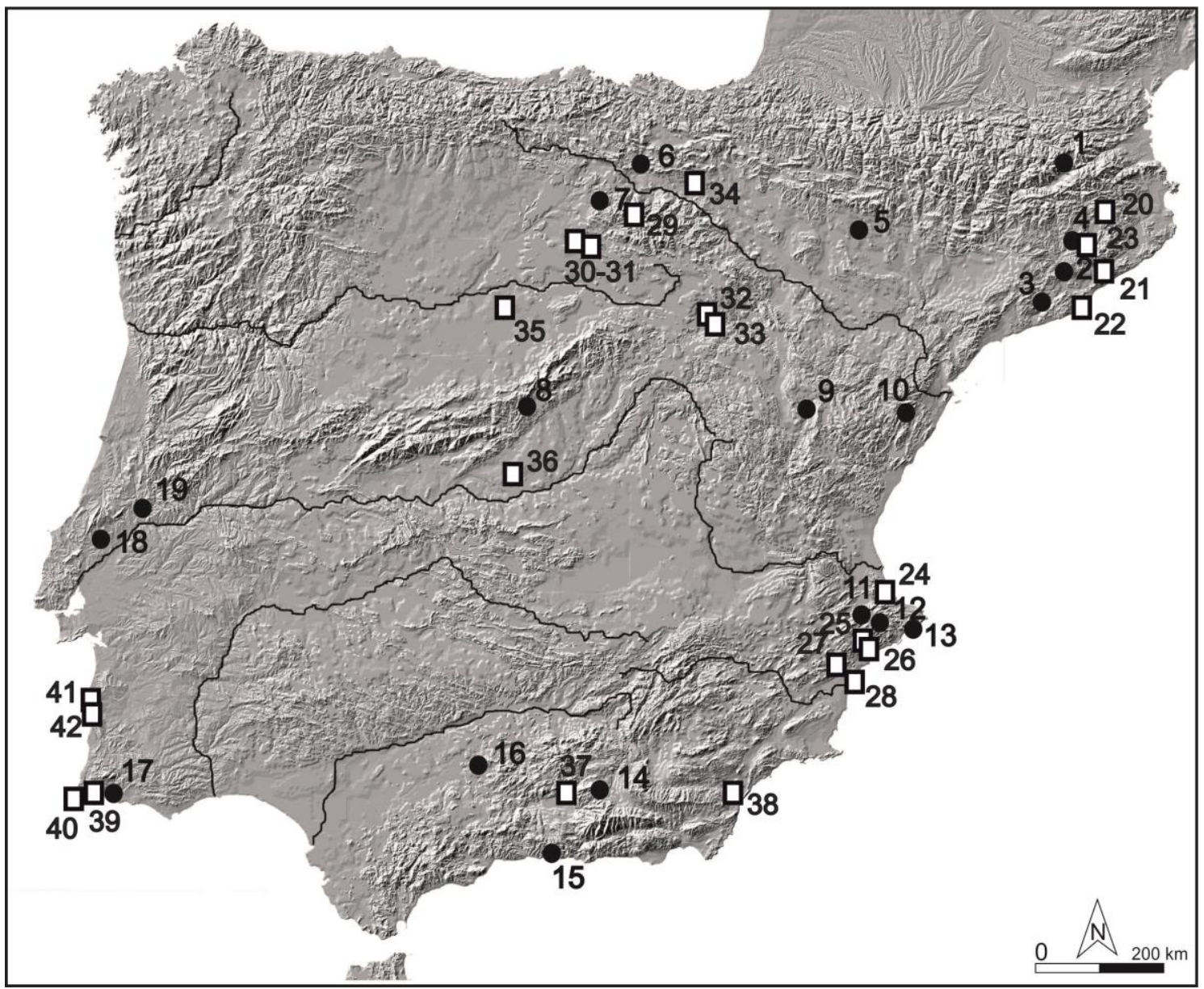

Fig. 1. Distribution of the main Early Neolithic settlements in the Iberian Peninsula. Caves with stratigraphy of the Early Neolithic in the Iberian Peninsula cited in the paper: 1. Balma Margineda; 2. Cova del Toll; 3. Cova del Frare; 4. Can Sadurní; 5. Chaves; 6. Peña Larga; 7. El Mirador; 8. La Vaquera; 9. Botiquería de los Moros; 10. Cova del Vidre; 11. Cova de 1'Or; 12. Cova d'en Pardo; 13. Cova de les Cendres; 14. Cueva de la Carihuela; 15. Cueva de Nerja; 16. Cueva de los Murcielagos; 17. Ibn Anar; 18. Almonda; 19. Caldeirâo.

Main open-air sites of the Early Neolithic in the Iberian Peninsula: 20. La Draga; 21. Carrer d'en Xammar; 22. Caserna de Sant Pau-Plaça Madrid; 23. Les Guixeres; 24. Barranquet; 25. Benàmer II; 26. Mas d'Is; 27. Calle Colón; 28. Tossal de les Basses; 29. El Prado; 30. Molino de Arriba; 31. El Congosto; 32. La Revilla del Campo; 33. La Lámpara; 34. Los Cascajos; 35. La Cañadilla; 36. La Paleta; 37. Castillejos; 38. Cabecicos Negros; 39. Vale Boi; 40. Cabranosa; 41. Vale Pincel I; 42. Samouqueira II.

In this study, we synthesize and evaluate the archaeological information available on early Neolithic open-air settlements in the Iberian Peninsula (Fig. 1), dated to the VI millennium BC. We focus on open-air Neolithic sites, with evidences of domestication and material culture associated with Neolithic impressed ware, mainly dated above 6100 BP. These data enable us to infer the characteristics of households in the first farming 
communities that settled and spread through this territory, although we remain aware of the fact that their recognition and analysis remain limited.

\section{Conceptualization of Activity Areas and Households}

Households, as units of observation and analysis (Hirth 1993; Douglass and Gonlin 2012), can be approached from multiple theoretical perspectives, because they allow connections to be made between the partiality of the archaeological record and the different characteristics of the societies that maintained them. Other approaches can be added to the functionalist analysis of households, such as the observation of identity and cultural singularity, the symbolism of spaces and objects, or sociological questions, such as the differentiation of public and private spaces, or even the roles enacted by individuals in domestic spaces, according to gender or age (Stevanović 1997; Banning and Chazan 2006; Souvatzi 2008; Castro et al. 2013, Beaudry 2015). Here, we seek to define the characteristics of domestic groups in a specified society (Bate 1998), both at a productive and reproductive level, from the research perspective and conceptualization developed from Social Iberoamerican Archaeology (Fig. 2) (Bate 1998; Acosta 1999; Flores 2007).

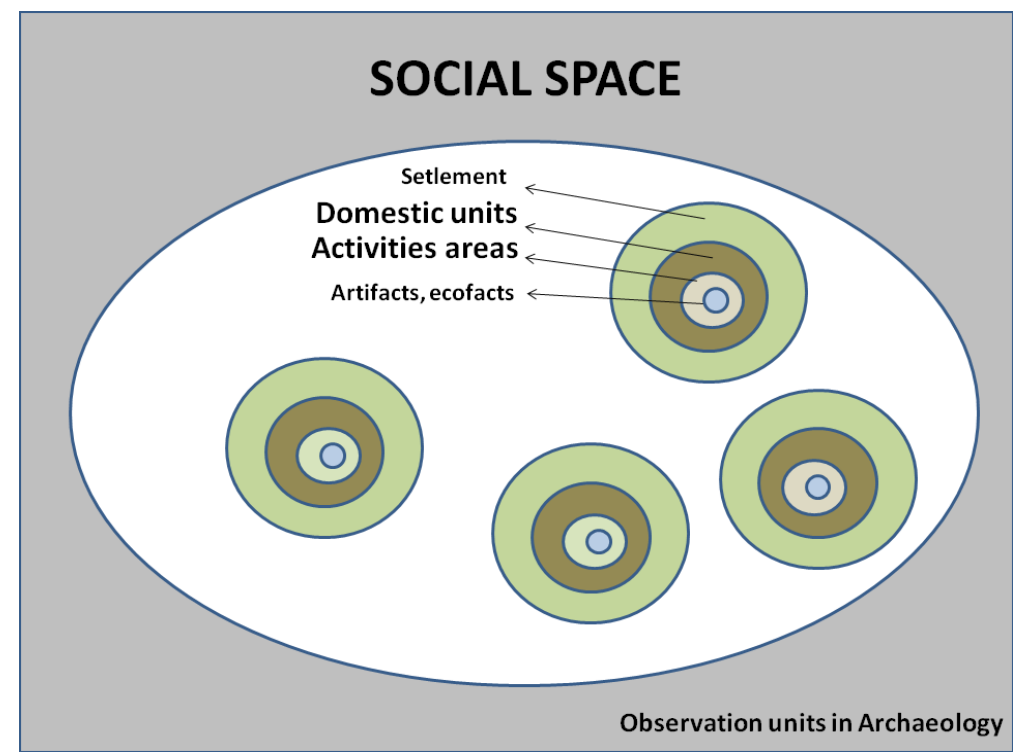


Fig. 2. Main observation units in Social Iberoamerican Archaeology.

This can be accomplished by determining labor processes carried out through time and materialized in a space by each domestic group in their daily life (Veloz 1984; Whittle 2012; Gillespie 2012). Nevertheless, it is very important always to bear in mind that in most cases only a small part of these labor processes materializes in the archaeological record.

Recognizing households and their activity areas in archaeological contexts is crucial, as they are the materialized expression of residence, production-consumption, and biological, symbolic and ideological reproduction of each domestic group (Hendon 2007; Douglass and Gonlin, 2012; Hirth 2012; Castro et al. 2013) (Fig. 3). In their temporal development, households offer a fuller understanding of the organization of domestic spaces, and the inference of essential aspects of the social organization of a specific society (Flores 2007; Hendon 2007; Castro et al. 2013).

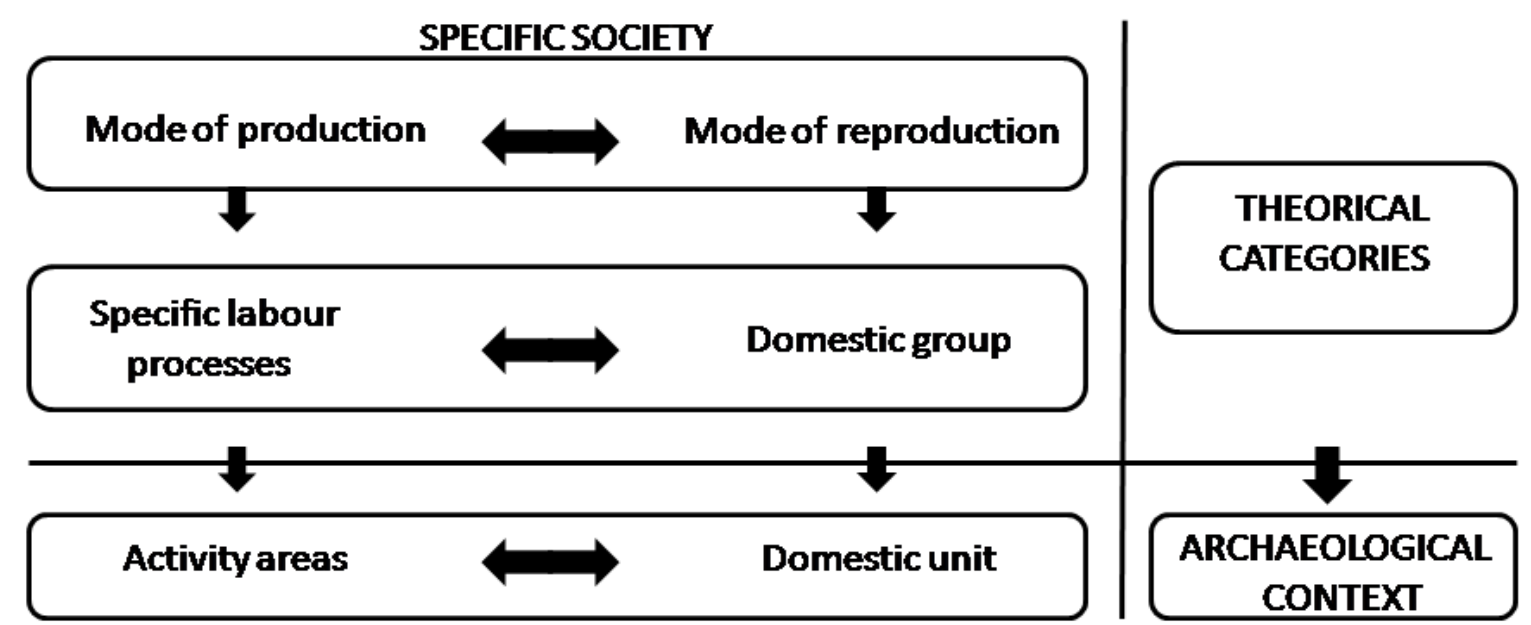

Fig. 3. Main theoretical categories in Social Iberoamerican Archaeology. 
For this reason, we approach the study of the Neolithic archaeological record considering these two units of observation and analysis: activity areas and households or domestic units.

On the one hand, activity areas can be defined as the materialization, in archaeological contexts, of work processes carried out at one or several different moments in a given period of time (Fig. 3). They can be recognized by detecting the locations where these activities developed simultaneously, successively and recurrently over time (Acosta 1999). They can be considered the empirical manifestation of one or more activities necessary for a certain society. These activities occur in a defined space, in association with the artifacts used for these tasks and with their results that reflect accumulated labor (Flores 2007: 64). They are the materialization of social labor, whose spatial, temporal, and functional associations constitute the modes of labor of every society (López Aguilar 1990: 102).

On the other hand, a household or domestic unit constitutes the empirical manifestation to a greater or lesser degree of conservation of the activities, temporally and spatially determined, carried out in a recurrent way by every domestic group, which are socially necessary for the subsistence and reproduction of the members of the unit. The cultural forms establish the characteristics of each activity carried out, as well as the use of space, although many variables could determine the organization and spatial distribution (Flores 2007). Be that as it may, we must insist on the need to avoid "equivalence transformations" (Schiffer 1985), a concept widely discussed in behavioural archaeology. This concept highlights the fact archaeological reality does not faithfully reflect the (systemic) reality of everyday life, because the first may have been altered by 
a vast number of processes. In other words, we must bear in mind the "Pompeii premise" problem and consider that the materiality recognized in an archaeological record and that would be included in a so-called domestic unit, hardly corresponds to a single or concrete moment of everyday life. On the contrary, the set of elements and objects that we document will come with a wide range of problems (Hirth 2012), and represent the accumulation in a given space of a set of activities carried out by the group over an ill-defined period of time -from a few days to several generations. It will necessarily reflect an accumulation of the work performed in the occupied space, and not only the work performed by the members of that domestic group. The quality and magnitude of the work invested are fundamental indicators to deduce features relating to the capacity and social organization of these groups.

The concepts of the domestic unit and the domestic group should not be confused (Laslett 1972; Flores 2007; Douglass and Gonlin 2012; Gillespie 2012). The domestic group is the basic organizational unit in every human society, referring to all the individuals who live in common and shared physical space, according to a series of varied relations, such as kinship, adhesion, affinity and politics. In so doing, they satisfy their needs and thus avoid their disintegration. As a unit of social reproduction, they carry out different activities and social practices, such as biological reproduction, care, protection, teaching, and the production and consumption of goods (Souvatzi 2008; Castro et al. 2013). These activities are regulated by a system of social relations which sustain the social group and are subjected to a superstructure by various aspects and social rules (Flores 2007: 82).

Given that the social actions of any domestic group are subject to change (Hofmann 2012), the empirical evidence of households in the archaeological record can take multiple forms (Castro et al. 2013), which can be difficult to interpret (Banning and 
Byrd 1987:322). These limitations are present in the analysis of the partial archeological record for the early Neolithic households in the Iberian Peninsula.

\section{Archaeological evidence of the first Neolithic communities in the Iberian Peninsula}

Towards 5700-5500 cal BC, in the Iberian Peninsula, a considerable number of archaeological open-air sites have documented evidences of human communities with a farming way of life (e.g, Zapata et al. 2004; Peña-Chocarro et al. 2013; García Puchol et al. 2018) ${ }^{1}$. At the beginnings of this process, these groups would arrive to the Iberian Peninsula by sea from the Italian, French and North African coasts (Zilhão 2011; Borrell and Gibaja 2012; Isern et al. 2014; Martín et al. 2017), but also from inland European territories, crossing the Pyrenees (Szécsényi-Nagy et al. 2017).

In total, for the timescale between 5700 and 5100 cal BC, almost fifty archaeological sites have been excavated to date (Table 1). A considerable number of them, dating from C. $5700 / 5500$ cal BC, are concentrated in the basins of the Ter and Llobregat rivers, the coasts of Tarragona and between the Serpis and Gorgos basins, where the socalled "Cardial formative horizon of impressed ceramics" originates (Bernabeu et al. 2009; Soler et al. 2013; Bernabeu and Martí 2014). They are also located in the coasts of Málaga (Aura et al. 2013; Martín et al. 2017), Cádiz (Lazarich and Ramos 2002; Ramos et al. 2006a; 2006b); and Algarve (Carvalho 2008; Goufa and Carreia 2016). Nevertheless, Neolithic settlements only from 5400/5300 cal BC started to be identified in the rest of the basins from the interior and the West of the Iberian Peninsula (Camalich and Martín 2013; Isern et al. 2014; Rojo et al. 2012; 2015; Carvalho 2008; 2012; 2015; Tavares da Silva and Soares 2015; Jiménez-Echeverría, 2017a; e.g.), as a result of population stabilization and expansion in these areas.

\footnotetext{
${ }^{1}$ In recent years, several works with the absolute dates of these sites have been published (Rojo et al. 2012: 581-603; García Puchol et al. 2016, 2018; Martín et al. 2017, e.g.).
} 
For years, the settlement pattern in this period has been characterized as the occupation of river valleys, near fertile lands and water sources. At present, the archaeological recognition and the material and sequential characterization of the first farmers in the Iberian Peninsula still comes predominantly from the excavation of cave sites (Fig. 4).

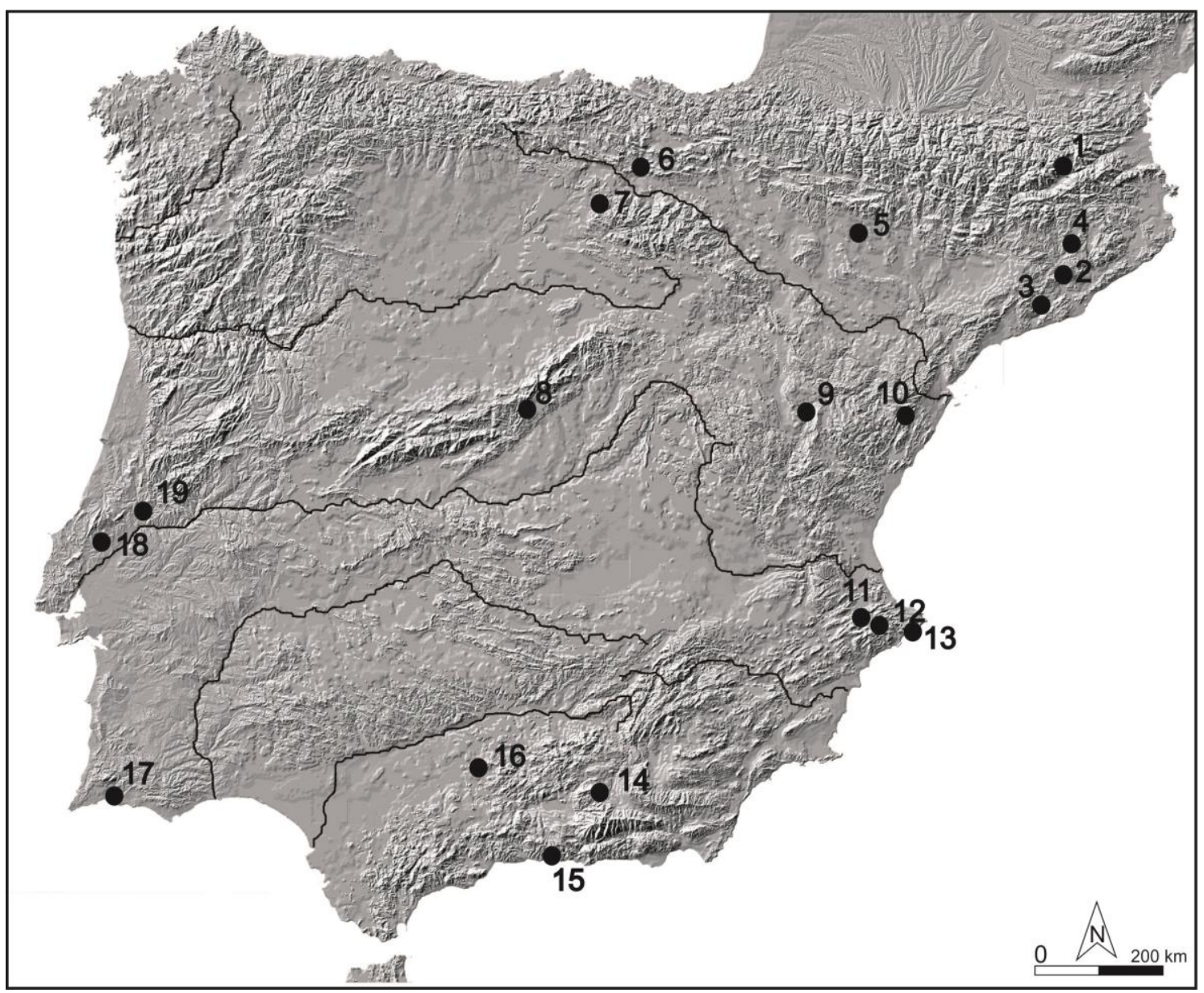

Fig. 4. Caves with stratigraphy of the Early Neolithic in the Iberian Peninsula cited in the text: 1. Balma Margineda; 2. Cova del Toll; 3. Cova del Frare; 4. Can Sadurní; 5. Chaves; 6. Peña Larga; 7. El Mirador; 8. La Vaquera; 9. Botiquería de los Moros; 10. Cova del Vidre; 11. Cova de l'Or; 12. Cova d'en Pardo; 13. Cova de les Cendres; 14. Cueva de la Carihuela; 15. Cueva de Nerja; 16. Cueva de los Murciélagos; 17. Ibn Anar; 18. Almonda; 19. Caldeirâo.

Among the more than 70 Early Neolithic caves excavated in the Iberian Peninsula (Rojo et al. 2012), given the importance of their occupation sequence and quality of information, there should be highlighted: Balma Margineda, Cova del Vidre, Cova del 
Frare, Can Sadurní and Cova del Toll in Cataluña; Cova de l'Or, Cova de les Cendres and Cova d'en Pardo in the Valencian region; Cova de Chaves, Botiquería and Peña Larga in Aragón; Cueva de Nerja, Los Murcielagos and La Carihuela in Andalucía; El Mirador, la Vaquera in the Meseta and Caldeirâo, Almonda and Ibn Amar, in Portugal. The time sequences and the archaeological materials documented in some of these caves constitute the basic information for studying the organization and the transformations of the first Neolithic groups in this area. The approach and limitations of each archeological study resulted in the excavation of only small areas in many cases. Most of these excavations were limited -and still are- by many different factors, related to research objectives or budgetary and timescale constraints. This has hampered the recognition and study of the early Neolithic households.

However, this situation has changed in recent years. On the one hand, several research projects in open-air sites have been carried out, almost 15, and, on the other, recent rescue excavations have also documented a wide range of open-air sites. As a result of a high number of rescue archaeology excavations, many Neolithic open-air sites have been found. More than $65 \%$ of the Neolithic open-air sites were detected by rescue archaeology. Both types of excavations, rescue archaeology and research projects, have generated valuable results, constituting a quantitative leap in the knowledge of early agricultural groups in these territories.

For decades, different research projects targeting the study of the open-air Neolithic sites have been pursued. There are various examples that we can cite in different territories of the Iberian Peninsula. In the Meseta, the best quality information comes from the research project developed in the Soria sites of La Revilla del Campo and La Lámpara (Rojo et al. 2008; 2016). These have been complemented by other nuclei located in emergency excavations, among which El Prado (Alonso and Jiménez 2014; 
Alonso-Fernández 2017), Molino de Arriba (Alonso and Jiménez 2015), El Congosto (Rojo et al. 2016), La Cañadilla and La Paleta (Jiménez et al. 2008; Jiménez 2010). The same can be considered to apply to other areas such as the Ebro basin in its upper course (García Gazólaz and Sesma 2007, García Gazólaz et al. 2011), although the most significant examples are certain river basins in the eastern Iberian Peninsula. In the eastern Iberian Peninsula, we highlight the sites of La Draga, Font del Ros and Les Guixeres, in Cataluña, and Mas d'Is, in the Valencian region (Fig. 5).

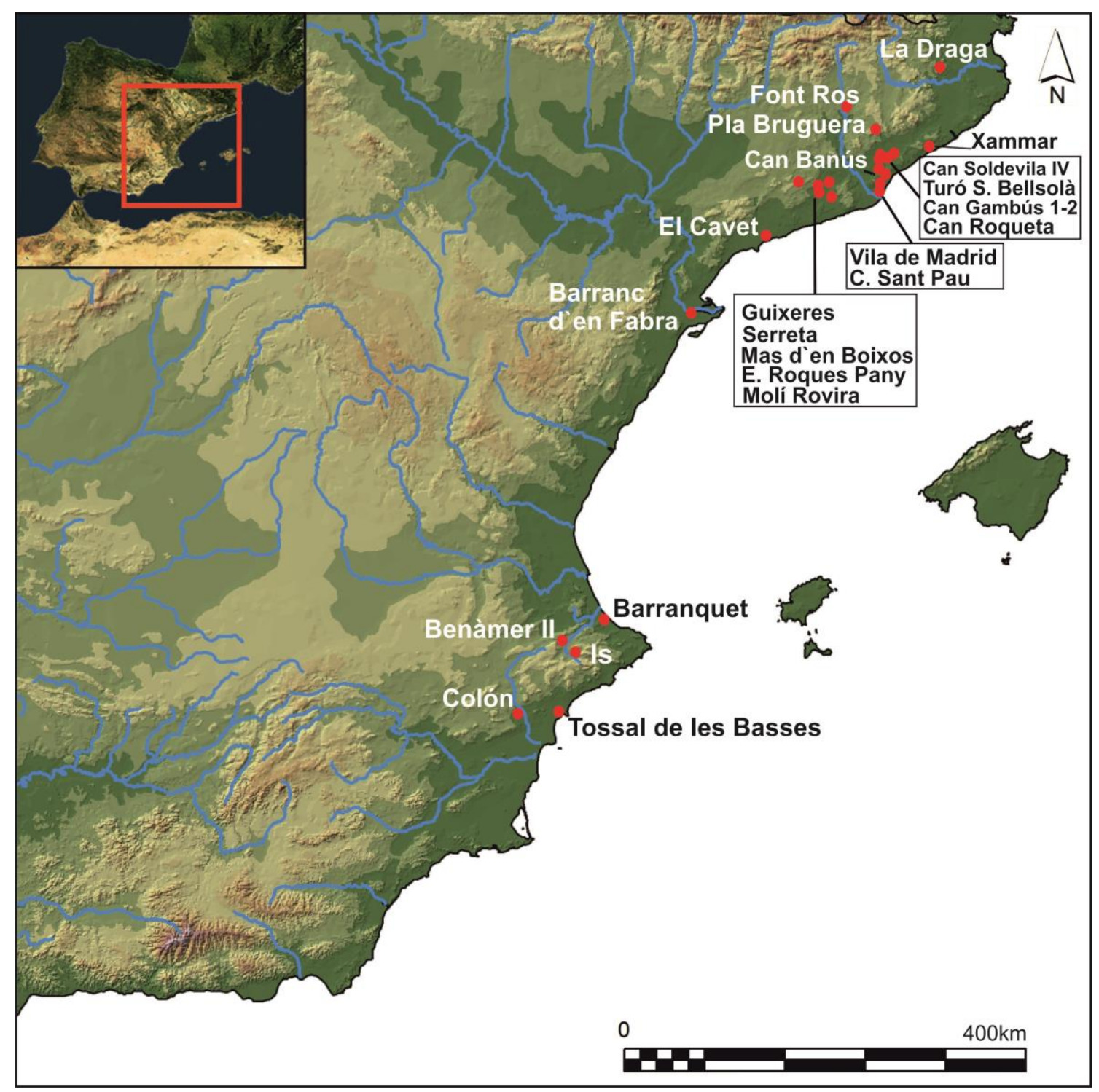

Fig. 5. Main open-air Neolithic settlements in the East of the Iberian Peninsula. 
Nevertheless, most of the available information comes from rescue archaeology (see Table 1 for details), associated with urban development during the last few decades. Most of the sites detected are located mainly in the Llobregat river valley and the Catalan coastal depression, today one of the most populated areas of the Iberian Peninsula. The same is true of certain southern sites, located in the Valencian region: El Barranquet, Benàmer, Calle Colón, or even sites with a great surface excavated and good quality of information, dated between the end of the 6th millennium and the beginnings of the 4th millennium cal BC, such as Tossal de les Basses (Rosser and Soler 2016) or Costamar (Flors 2010).

Rescue archaeology has made it possible to carry out large-scale open-area excavations at many sites of previously limited access, despite persisting spatial constraints. This has enabled archeologists to prepare more accurate interpretations of the structures. The possibility of excavating large areas in a short time period offers economic and timescale advantages over excavations related to research projects. These circumstances also typify projects in other Western Mediterranean regions (for example, Radina and Sarti 2002; Perrin et al. 2011; 2014).

In any case, despite the lack of a direct relationship between the surface area excavated and structures found, open-air sites where a considerable area was excavated rendered a larger and more diverse group of findings. For now, these settlements -La Draga (Bosch et al. 2011), Carrer d'en Xammar (Morales et al. 2010), Caserna de Sant Pau (Borrell and Gibaja 2012), Los Cascajos (García Gazólaz et al. 2011), El Prado (Alonso- 
Fernández 2017), Revilla del Campo (Rojo et al. 2008), Benàmer II (Torregrosa et al. 2011), Mas d'Is (Bernabeu et al. 2003), Vale Pincel I (Tavares and Soares 2015; Soares et al. 2016) and Vale Boi, at El Algarve (Carvalho 2008)- provide a more complete interpretation of early Neolithic materials and structures.

\section{Deciphering the archaeological record of the early Neolithic in the Iberian Peninsula}

As commented above, the archaeological record for the open-air settlements of the first Neolithic groups in this area is partial. This is not only because of the spatial limits of the reduced area excavated in many cases, but also due to the multiple natural and human post-depositional processes that have affected the record, preventing an extensive preservation of the archeological remains. Sometimes, however, the spatial limitations of the excavated area, for example in the case of Cabecicos Negros (Vera, Almería) (Goñi et al. 2012) merely lead to records of sedimentary deposits that are difficult to interpret. And in other cases, as in El Barranquet (Oliva, Valencia) (Esquembre et al. 2008), palaeochannels are found that were used as waste areas for all types of consumption remnants and objects (Fig. 6). Nevertheless, at the open-air sites studied, different types of structures were identified (Table 1). 

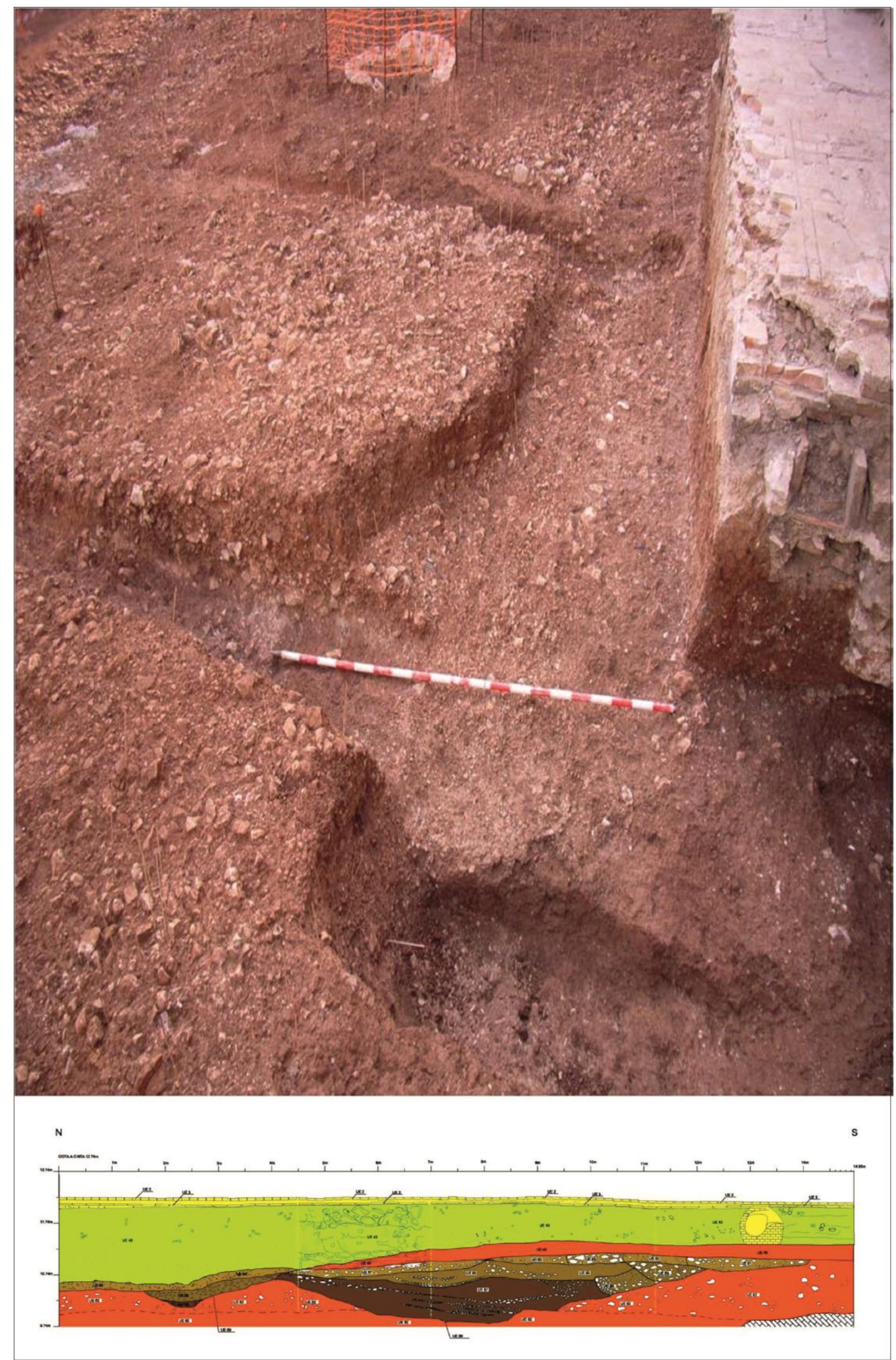
Fig 6. Photograph and section of the paleochannel excavated at El Barranquet (image courtesy of M. A. Esquembre).

According to formal criteria, the documented structures have fallen until now into two categories:

1. Paved surfaces, difficult to interpret, although usually associated with palaeosoils or occupied soils.

2. Holes made in the subsoil. These are concavities or depths created artificially in the earth. Based on their formal characteristics, - i.e. conditioning or not of the interior walls, their dimensions and archaeological records contained in their filling-different interpretations of their uses or purposes have been put forward, with varying denominations according to authors and traditions. Thus, silos storage structures-, holes or burial pits have been considered; holes have been interpreted as drinking troughs or small wells; pits or holes are difficult to interpret, although they are mostly used as dumps or waste areas; combustion structures (Fig. 7), hearths or cooking pits -also called Polynesian ovens- of varying sizes, morphology and filling composition; holes for retrieving clay or soil; holes or pits for posts, for hut floors, that usually tend to be oval and several meters in diameter; and, finally, trenches i.e. long and narrow ditches dug in the subsoil of different widths and depths for varying purposes. 


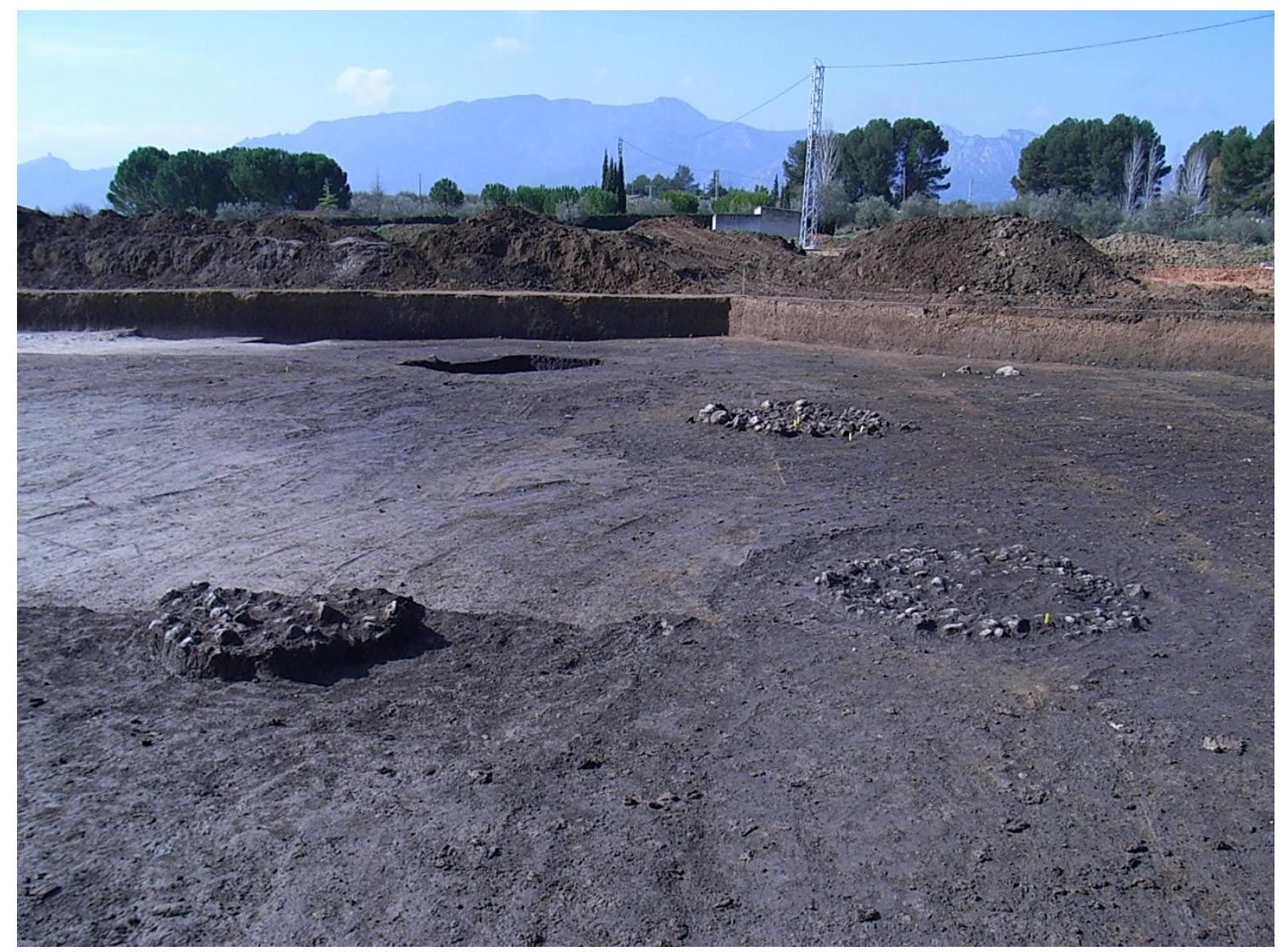

Fig. 7. Circular cobble-paved structures excavated in Benàmer II.

Reviewing the archaeological record analyzed here (Table 1), in most cases, negative structures interpreted as silos have been found. These structures sometimes appear to be clustered in groups. Among others, the presence of silos has been separately observed in Pla de la Bruguera, Turó de Can Bellsollà, Can Gambús 1, Can Gambús 2, La Serreta, Mas d'en Boixos, La Esquerda de les Roques del Pany, Molí d'en Rovira or El Cavet (Bibliography in Table 1). In general, their morphological, pyriform or truncated features, have led to interpreting them as silos, added to the fact that, in sites such as El Prado (Alonso-Fernández and Jiménez-Echeverría 2014: 43; Alonso-Fernández 2017), they were built on rocky geological bases, with clay covered walls and floors. Moreover, in several cases, palynological studies have allowed interpreting their use as 
silos, given the presence of cereal pollens, which is the case of Sector 119 of La Paleta, which in turn was used to date their moment of use and abandonment (Jiménez 2010: 324); this is also the case of El Prado (Alonso and Jiménez 2014), given that 5\% of fabaceae was found. Furthermore, the so-called Sector 3 was documented in La Lámpara, and interpreted as a silo that had been shut following a ritual, based on the layout and characteristics of the materials left inside (Rojo et al. 2008: 394-398). In any case, the difficulty is to determine whether they are contemporary, this being one of the major problems affecting the study of storage processes and their management within settlements. In any case, not all the pits seem to have been silos, especially the small ones with irregular shapes. These could have had different functions or have resulted from different activities, such as clay extraction, as has been proposed at several French archaeological sites, including Pont de Roque-Haute (Portiragnes, France) (Guilaine et al. 2007: 46).

Among this wide range of recorded holes, worthy of note are those with a different typology, size and containing archaeological materials in their sedimentary fill. All that we can deduce from their characteristics is that a large part of them were amortized as waste areas. This is the case of Can Soldevila IV, Can Banús, El Carrascal, in El Prado next to silos, or Llano del Montico. In the latter case, pits or holes of different types and sizes were also used as funerary trenches, as has been widely observed throughout most of the peninsular territories. Individual or double burials -of men, women or childrenhave been found in the Plaça de la Vila in Madrid (Barcelona), Paternanbidea, Molino de Arriba, El Congosto, Alto de Rodilla and Fuente Celada (Rojo et al. 2016), as well as in La Lámpara, El Prado and El Retamar, although in these latter three cases, they are associated with other pit-type structures -trenches, silos, hearths, etc.-. 


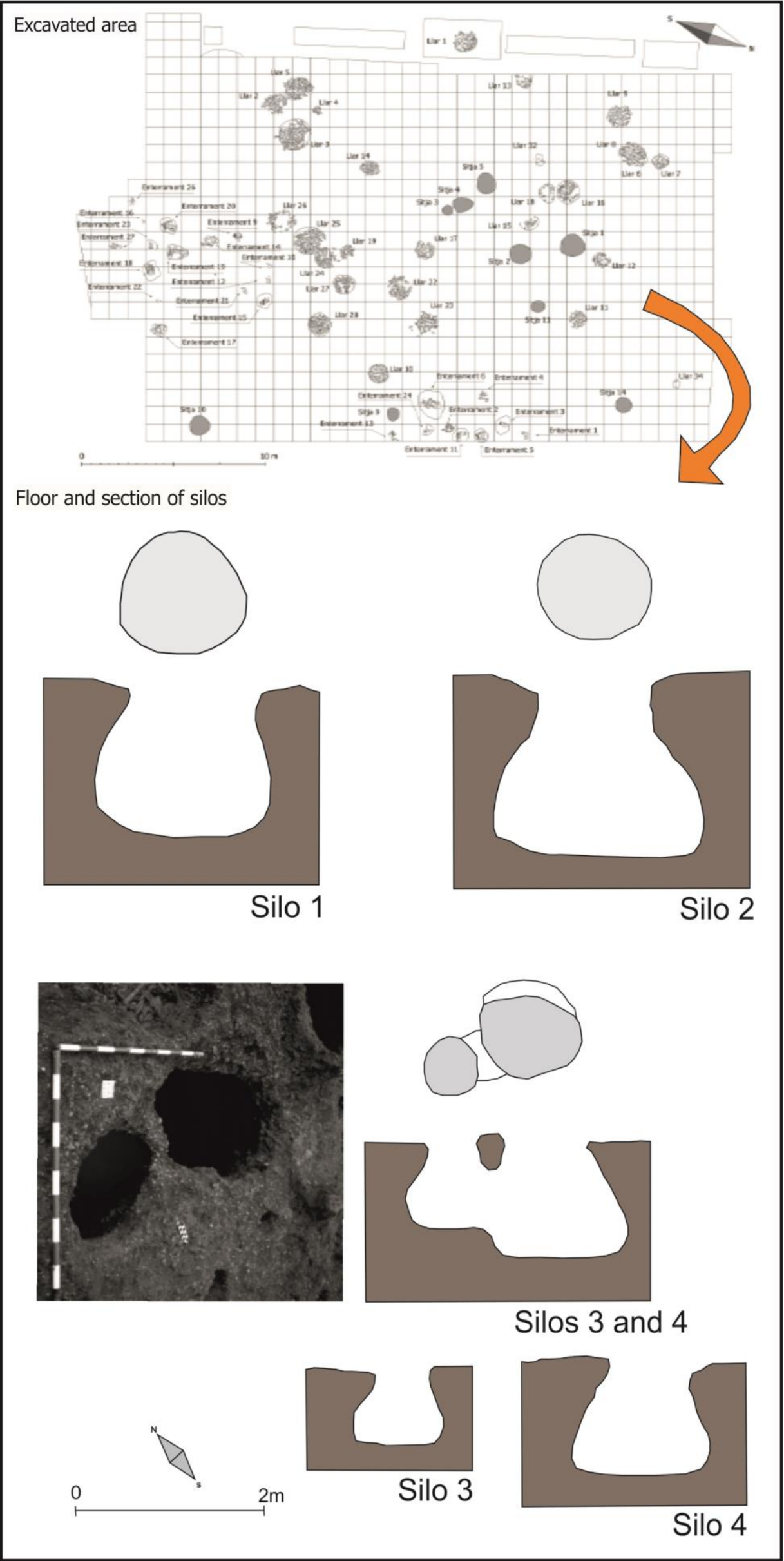


Fig. 8. Excavated area in the site of Caserna de Sant Pau (Barcelona). Ground plan and section of some of the silos documented. Figure based on M. Molist et al. (2008: 17, Fig. 2; 21, Fig. 4).

However, the sites in which combustion structures have been found are more numerous. These combustion structures include cobbled pits, also called Polynesian ovens (Vaquer et al. 2003, Fortó et al. 2008) or hearths, of different morphologies and sizes though they are usually shallow and paved with stones or thermo-altered blocks. Among others, we can mention La Cañadilla, Cortecampo II (Ramos 2007), Vale Santo, Cabranosa, Padrâo or Alcalar 7, considered in the latter case as a shell midden (Carvalho 2008, Goufa and Carreia 2016).

On the other hand, it should be noted that silos, pits and structures, also associated with concentrations of artifacts and debris, have usually been recorded in open-air sites that were possible to excavate extensively over an open area. Significant examples in different regions of the Iberian Peninsula are, for example: Vale Pincel I (Tavares and Soares 2015; Soares et al. 2016) with combustion structures, pits and artifact concentrations; Can Roqueta (Oliva et al. 2008); or Los Barruecos (Cerrillo 2006), where it was possible to recognize the presence of combustion structures, silos and artifact concentrations; or in La Paleta (Jiménez 2010), where pits, silos and ditches were found.

In other archaeological sites, pits are located either close to clusters of artifacts, as at Font del Ros (Terradas et al. 1992; Morales et al. 2010), close to waste areas next to hearths, or adjacent to combustion structures, such as in Caserna de Sant Pau (Molist et al. 2008; 2009; Borrell and Gibaja 2012) (Fig. 8). In the latter case, several analyses have implied a food processing-consumption area, associated with cobbled structures. At other sites, pits are associated with long trenches containing considerable amounts of 
archaeological materials related to charcoal concentrations and linked to post-holes, identified as dwelling-pits, such as at Les Guixeres (Mestres 1981-82), Xammar (Pou and Martí 2005) or La Velilla (Jiménez 2010: 224), where a hearth or a central structure was recognized.

In general, some of these pits could have been used or re-used for funerary purposes, with multiple the examples documented (Pou et al. 2010; Rojo et al. 2016). At other archaeological sites, different structures were identified and interpreted as dwelling-pits or dwellings with different activity areas, e.g. Los Cascajos (García Gazólaz and Sesma 2007), La Revilla del Campo (Rojo et al. 2008), El Prado (Alonso-Fernández 2017), Vale Boi (Carvalho 2008), Benàmer II (Torregrosa et al. 2011) and Mas d'Is (Bernabeu et al. 2003).

The site of Los Cascajos (Los Arcos, Navarra) (García Gazólaz and Sesma 2007; García Gazólaz et al. 2011) has a very large surface area -more than $30 \mathrm{Ha}^{-}$, with a long sequence of occupation running almost uninterruptedly throughout the Neolithic. Of the 550 negative structures interpreted as pits, post-holes, silos, hearths, waste areas and buried burial pits, very few correspond to ancient times -mainly E351, a combustion structure, and the burial structures 497 and 183-. In fact, 8 circular huts have been documented, delimited by post-holes, between 6 and $8 \mathrm{~m}$ in diameter; 36 were buried with 34 negative structures. Of these, 23 tombs with 25 individuals are arranged in a circle on an area of about $550 \mathrm{~m}^{2}$, constituting a kind of necropolis area. 
In La Revilla del Campo (Torralba del Moral, Soria) (Rojo et al. 2008: 357), an area of around $2000 \mathrm{~m}^{2}$ could be excavated, leading to the recording of 17 structures. These were circular holes of different dimensions -between $42 \mathrm{~cm}$ and $2.2 \mathrm{~m}$ at the top and a depth between 19 and $160 \mathrm{~cm}^{-}$, excavated in the rocky substrate. In the sedimentary fill that clogged these structures were numerous archaeological remains. Structures 2 and 13 stand out. Structure 2, called a complex space, contains ditches within it, burned clay fragments and circular structures. Structure 13 consists of two circular enclosures covering an area of $194 \mathrm{~m}$. In its interior area, post-holes were documented in the smaller enclosure and in the main enclosure, a double line of trenches were found in a semicircular shape, representing a possible access area. Inside there are post-holes as well. A possible hearth was detected within the inner space.

In the case of the settlement of El Prado (Pancorbo, Burgos) (Alonso-Fernández 2017), a group of 50 negative structures corresponding to two different times during the Early Neolithic, could be excavated over an area of about $4605 \mathrm{~m}^{2}$. They correspond to the type of site referred to as "pit field". The study and interpretation of the set has made it possible to propose the verification of two clear groupings of structures of different types -silos, ditches, a combustion structure, burial pits and structures related to the use of water- that allow to deduce the existence of two non-contemporary living units (Jiménez-Echeverría 2017b), separated by about 250 years. The different structures and outdoor activity areas are distributed in an organized manner in the occupied space, where a storage area can be differentiated by the concentration of silos, funerary pits towards the central zone where the living unit would be located, and numerous pits, structures of combustion and wells/troughs somewhat further away. This site, which 
could be interpreted as a farm, would exceed 0.30 Ha (Alonso-Fernández and JiménezEcheverría 2017: 192). Stable isotope analyses show the proximity of the cultivation fields to the settlement and the consumption of C3 type plants (Pérez and López 2017). The palaeodiet analyses of the buried individuals show the importance, in particular, of the presence of cereals and legumes (Fernández-Crespo and Schulting 2017). These data, in addition, are confirmed by traceological studies, that indicate a notable presence of sickle and harvest work elements (Lazuén and González-Urquijo 2017).

In Vale Boi (Carvalho 2008), in addition to cobbled structures, two concentrations of cobblestones were recorded, interpreted as a possible living area or hut floor. In this soil, a combustion structure of $70 \mathrm{~cm}$ in diameter and a circle of blocks that may have been used as a storage shelf were found. Its excavators believe it may have been a residential campsite, with no more than 3-4 huts.

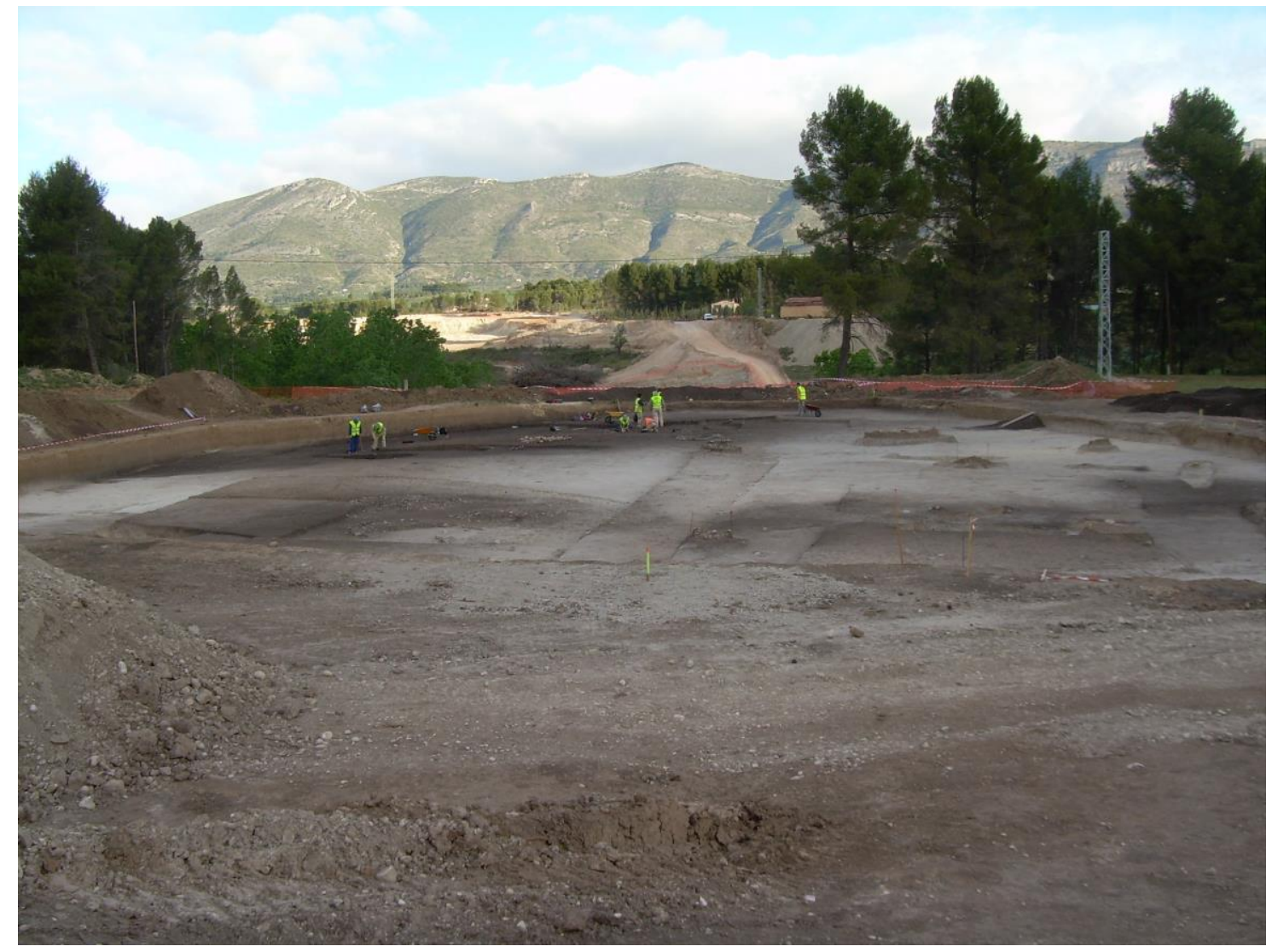


Fig 9. View of the open area excavated surface in Benàmer II.

In the occupation phase of Benàmer II, the excavated area in Sector 1 had an irregular polygonal shape of $1968 \mathrm{~m}^{2}$ (Fig. 9). It was covered by different contemporary archaeological strata as well as of the Iberian period (Torregrosa et al. 2011: 21-22), which at some points affected the Neolithic strata. The different Neolithic layers and structures defined an occupation floor and were distributed in two areas inside Sector 1. Most of the structures were documented in the northwestern area associated with two large overlapping strata. Linked to these, with a surface area of $700 \mathrm{~m}^{2}$, three complete and two partially preserved structures were found, with an elliptical or almost circular shape, and variable dimensions of 1,20-2,15 $\mathrm{m}$ in diameter (Fig 10). They were composed of fire-cracked limestone pebbles and very small charcoal fragments. In this context ceramics, mollusks, flaked stone and grinding materials appeared. Some ceramic fragments from several vases were widely scattered over this surface. Altered bone fragments and hardened daub building remains were also documented. The fact that one of the cobbled structures was superimposed over the rest and that the structures were 3-4 m apart supports the interpretation of these remains as a specific productionconsumption area. These combustion structures appear to have been used recurrently over the occupation period. 


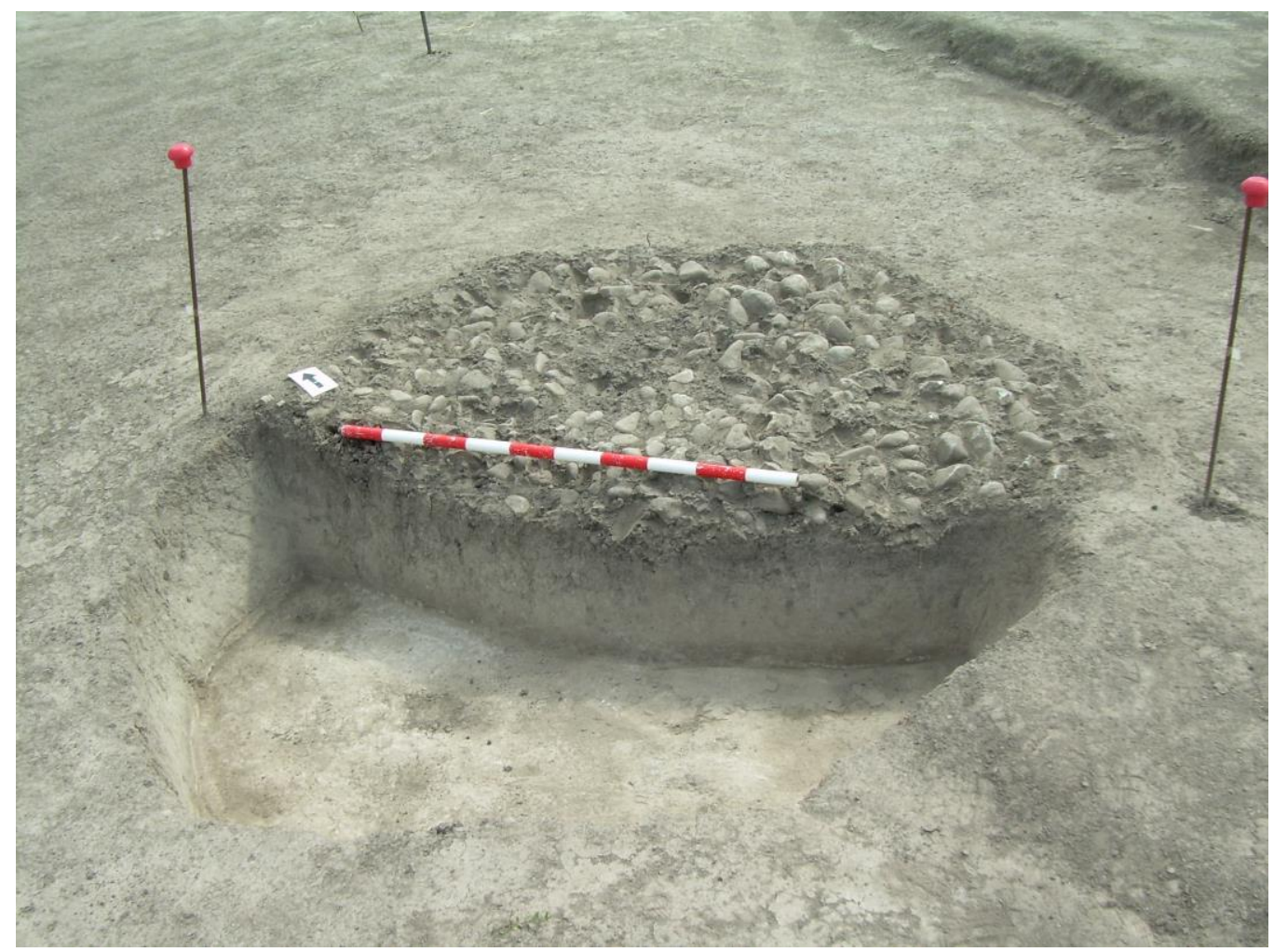

Fig. 10. Cobbled structure of Benàmer II.

In the southern part of this sector, at least three different areas were documented (Fig. 11). To the southeast, a homogeneous archaeological layer contained dark clayey sediment with some pebbles and gravel. In this irregular space of less than $120 \mathrm{~m}^{2}$, lithic debris were found, together with a Cardial ceramic fragment, abundant wheat pollen (López Sáez et al. 2011: 111), and a partially preserved stone grinder (Jover 2011) of $60-70 \mathrm{~cm}$ length and $36 \mathrm{~cm}$ deep and thus barely transportable. Two meters to the west, a large pit of only $40 \mathrm{~cm}$ deep was filled with dark brown sediment composed of clays, silt and gravels but without archaeological remains. The upper strata showed hardened daub fragments and flaked lithic remains. Having an irregular elliptical ground plan, of more than $3 \mathrm{~m}$ in diameter and more than $8 \mathrm{~m}^{2}$ at its base, this pit appears to be a dwelling-pit, similar to the ones documented in other sites, located not far away although slightly more recent, such as Tossal de les Basses (Rosser and Soler 2016) or, in the French Mediterranean area, in Mas de Vignoles X (Perrin et al. 2011). Lastly, to 
the southwest of this pit an irregular area of dispersed pebbles contained several cores and flint flakes.
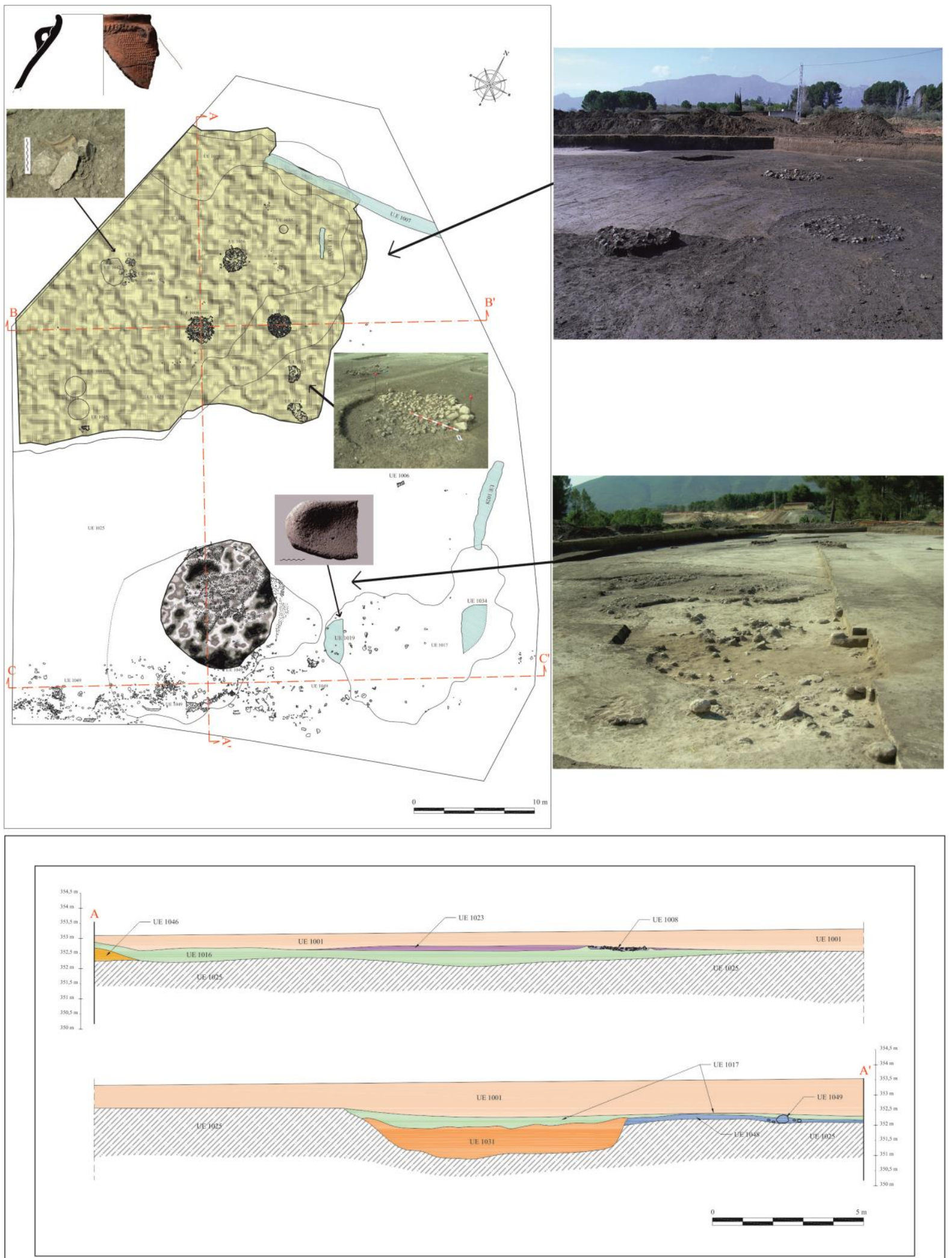
Fig 11. Excavated area in sector 1 of the site of Benàmer (Muro d'Alcoi, Alicante). Photographs show some of the structures and materials excavated.

Excavations at Mas d'Is have documented several small-diameter post-hole trenches, interpreted as dwellings (Bernabeu et al. 2003) (Fig. 12). The one designated as House 2, partially preserved, appears to be the oldest. The overlying House 1, rectangular in ground plan with an apsidal end, was apparently built from wooden posts and had a compartmentalized interior. To the west, different structures of gravel and mediumsized cobble were excavated, but rendered few archaeological remains. In the eastern area, no structures were found, but flint tools and flakes appeared. Both possible dwellings were constructed and used between 5600-5000 cal BC (Bernabeu and Martí 2012: 396). These kinds of buildings, of considerable size and having one apsidal end, have been identified in other settlements from the Western Mediterranean, such as Passo di Corvo (Foggia, Italy), Casale del Dolce (Anagni, Italy) (Tiné, 1983; Pessina and Tiné 2008: 140), and -presumably- Baratin (Courthézon, France) (Sénepart 2009: $70)$.

Outside House 1, some $23 \mathrm{~m}$ away in Sector 82, lay the remains of a negative rectangular combustion structure. Measuring $2.50 \times 1.50 \mathrm{~m}$, the walls were firehardened and the interior was filled by fire-cracked stones and several sedimentary layers containing charcoal and organic matter. This structure, presumably for cooking, may have been connected to House 1 despite the distance between them. This dwelling was dated by short-life samples to $6600 \pm 50$ B.P. (Beta-166727 and Beta-162092: 5630-5480 cal BC [95\% confidence interval]) (Bernabeu et al. 2003: 43). Some $6 \mathrm{~m}$ west from the apsidal end of House 1, a fragment of a possible earthen oven was found, probably displaced from its original location. Finally, approximately $250 \mathrm{~m}$ west of 
Houses 1 and 2, another plausible dwelling was identified, as House 3, similar to House 1 but dated slightly later (c. 5500-5400 cal BC) (Bernabeu and Martí 2012: 399).

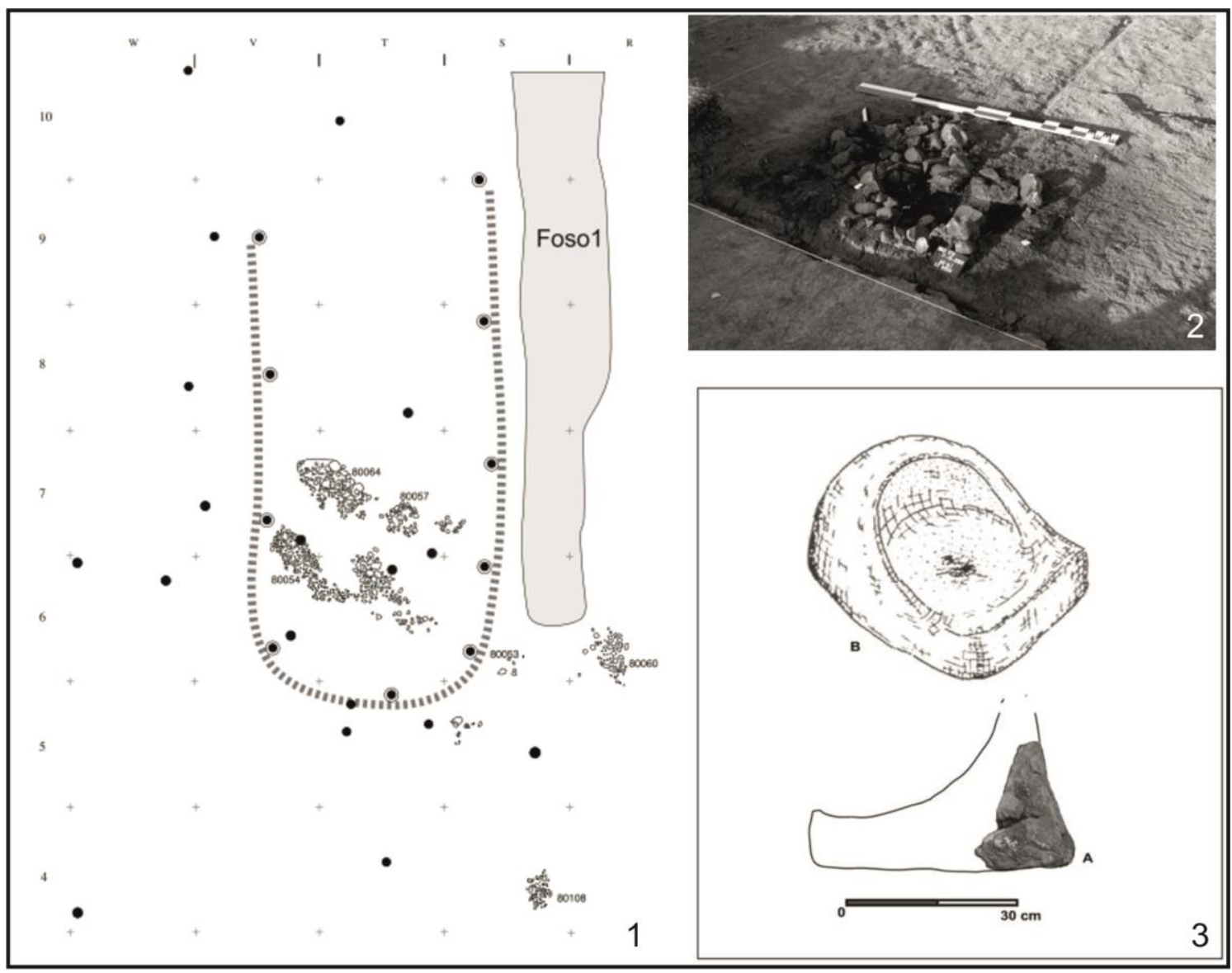

Fig. 12. 1. Reconstruction of the ground plan of house 1 in Mas d'Is (Penàguila, Alicante) (Bernabeu et al. 2003: 42, Fig. 2). 2. Detail of a combustion structure located outside house 1 (Bernabeu et al. 2003: 43, Lam III). 3. Restitution of a possible portable mud oven (Bernabeu et al. 2003: 44, Fig. 3).

One exceptional case was the Neolithic lacustrine and partially underwater settlement of La Draga (Bosch et al. 2000; 2011). After 16 years of archaeological excavations over a surface area of more than $726 \mathrm{~m}^{2}$, in the area $\mathrm{C}$, two stratigraphic levels were differentiated. The one corresponding to the earliest occupation, Level II, showed a settlement formed by what was interpreted as dwellings and open-air activity areas. There appear to have been 8 to 10 aligned rectangular buildings, oriented west to east, 
each with its own hearth. The buildings were identified by three to four rows of aligned posts. Several wooden planks, roof fragments, and objects made of organic materials were also found (Bosch et al. 2006). A wooden palisade apparently separated the dwellings from the working areas of the group, such as cultivated areas, granaries, communal fires, waste areas or fences.

On the other hand, in the most recent occupation, Level I, the wooden buildings appear to have been smaller and with approximately rectangular ground plans, insulated against the water. Open-air hearths and waste pits have been found. Certain oval and paved surfaces 3-4 $\mathrm{m}$ in diameter, some surrounded by posts, could have served as granaries (Bosch et al. 2000) and others as platforms to hold ceramic vessels. A comparable site is the settlement of La Marmotta (Anguillara Sabazia, Italy) (Fugazzola et al. 1993), in Italy. However, the fact that it is relatively late within the Early Neolithic may mean that this site gave rise to household groups after the firm establishment of the first farming communities.

The data discussed here offer preliminary evidence for recurrent structures and elements, associated in space and time, which would have constituted early Neolithic households, despite the scarcity of the evidence, their different degree of preservation and the limited areas excavated.

\section{Recognizing the households of the first Neolithic groups in the Iberian Peninsula}

Although the aforementioned sites have not been completely excavated, settlements such as Benàmer II (Torregrosa et al. 2011), Los Cascajos (García Gazólaz et al. 2011), El Prado (Alonso-Fernández 2017), as well as the slightly later ones with similar characteristics, Tossal de les Basses (Rosser and Soler 2016) or Barranc d'en Fabra (Bosch et al. 1996), illustrate how household spaces would be organized by the first 
farmers in this territory. Although the insides of the dwellings would have hosted different activities, apart from providing protection and lodging, open air areas surrounding these structures provided space for many daily activities. At a certain distance from these structures, appeared production-consumption areas, combustion structures, and clustered or isolated storage areas. There is no evidence to determine whether these latter spaces were open or enclosed, as at La Draga (Bosch et al. 2011), and also in the storage area of the $5^{\text {th }}$ millennium cal BC at Benàmer III-IV (Torregrosa et al. 2011). Other open-air activities not detected in archaeological records to date, such as livestock stabling -found in caves (Badal 1999; Badal et al. 2012)- or crop fields would not be located far from the domestic units. Some pollen studies, such as those carried out in Benàmer II (López Sáez et al. 2011) or El Prado (Pérez and López 2017) attest to this.

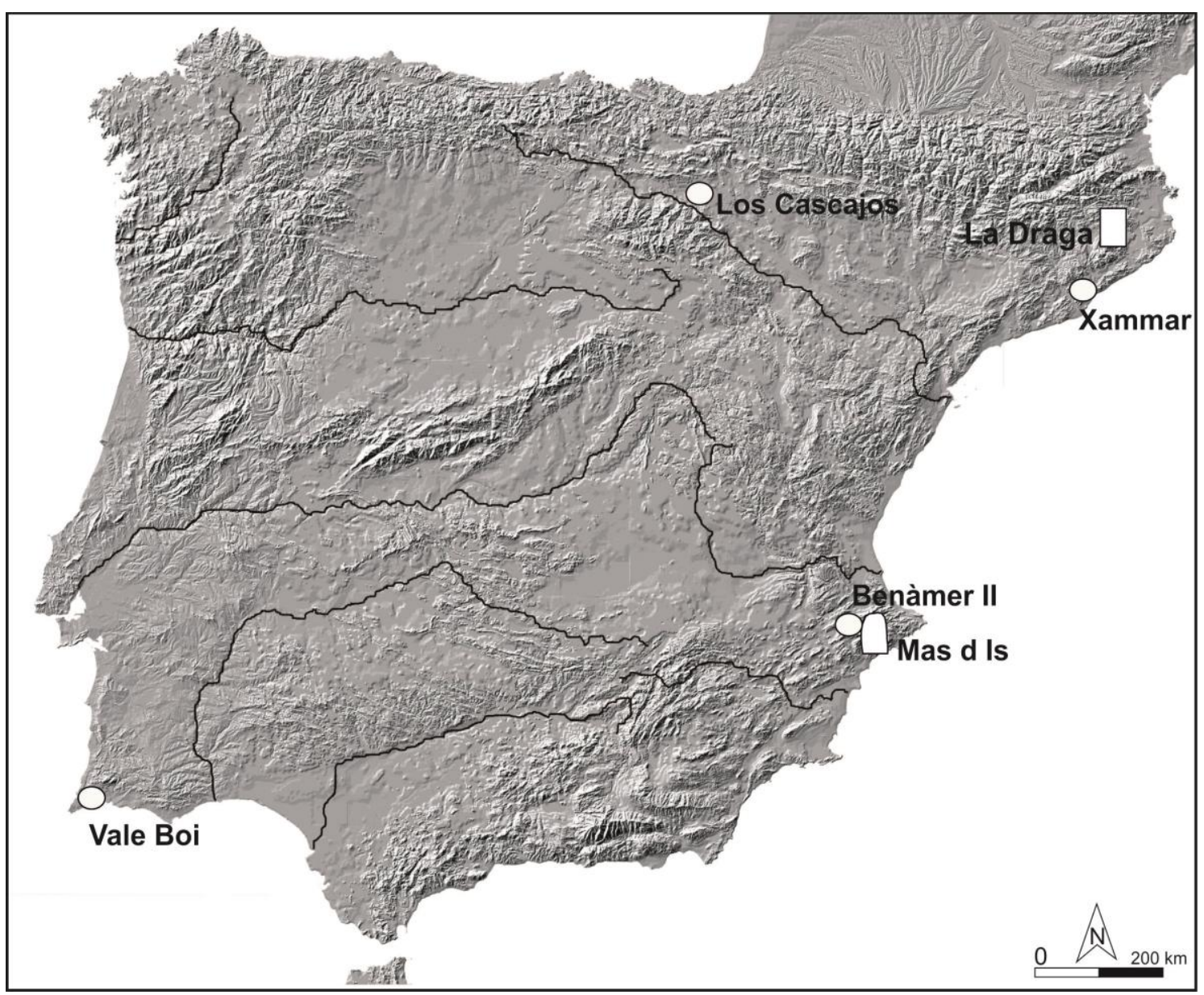


Fig. 13. Structures interpreted as buildings in Early Neolithic open-air sites in the Iberian Peninsula: rectangular plant houses, oval or oblong plant houses and rectangular-shaped houses with apsidal ends.

The archaeological record evidences at least two types of dwellings (Fig. 13). Firstly, rectangular structures with posts, resembled those found at La Draga, or with one curved side, as identified at Mas d'Is. Secondly, circular or oval pit-houses, such as the ones found at Xammar, Los Cascajos, Vale Boi or Benàmer II, were in some cases associated with post-hole foundation trenches, as at Guixeres de Vilobí. Similar examples have been reported in the Italian peninsula and along the French coast (Beeching and Sénépart 2009; Sénepart 2009; Perrin et al. 2011; 2014). Nevertheless, not all of the pits documented with similar characteristics would have functioned as pithouses (Suárez and Márquez 2014; Márquez and Jiménez 2014).

In many of the settlements analyzed, such as Los Cascajos, El Prado or Benàmer II, but also in French sites as Mas de Vignoles X (Nimes, France) (Perrin et al. 2011), having open-air activity areas distributed around the dwellings, such as storage silos and grinding areas, food-processing structures, and hearths, the minimum surface area of the domestic units could have reached $2500-3000 \mathrm{~m}^{2}$. In addition, there were pens, cultivated fields, and areas of storage of raw materials such as firewood. In total, the directly managed space could have occupied up to 3 hectares around the settlement. Other activities would have covered greater distances, but inside territories that were well-known and frequented by the inhabitants of the settlements: grazing areas, seasonal pens, shelters, caves used for storage, occasional shelter, inhumation or penning (Badal 1999; García Atiénzar 2010) and sites linked to community identity, etc. 
Regardless of whether some sites could be considered as occasional refuges, shell middens, quarries or flint workshops or areas of groupings or rituals, all usual activity locations for peasant groups ensuring complete land management, including intensive use of the territory where they are settled (Antolín 2015)-, a large part of the archaeological record analyzed here, despite its limitations, must necessarily correspond to structures and areas of activity that integrate what we call domestic units. Thus, the partially preserved evidence of the archaeological sites described above could be considered primarily as farm-like households, scattered throughout the areas where the first agrarian pastoral groups in the Iberian Peninsula initially settled (Bernabeu et al. 2008; Diniz 2008; García Atiénzar 2010; Jover 2013). These farms would have formed the basic units of social and productive organization.

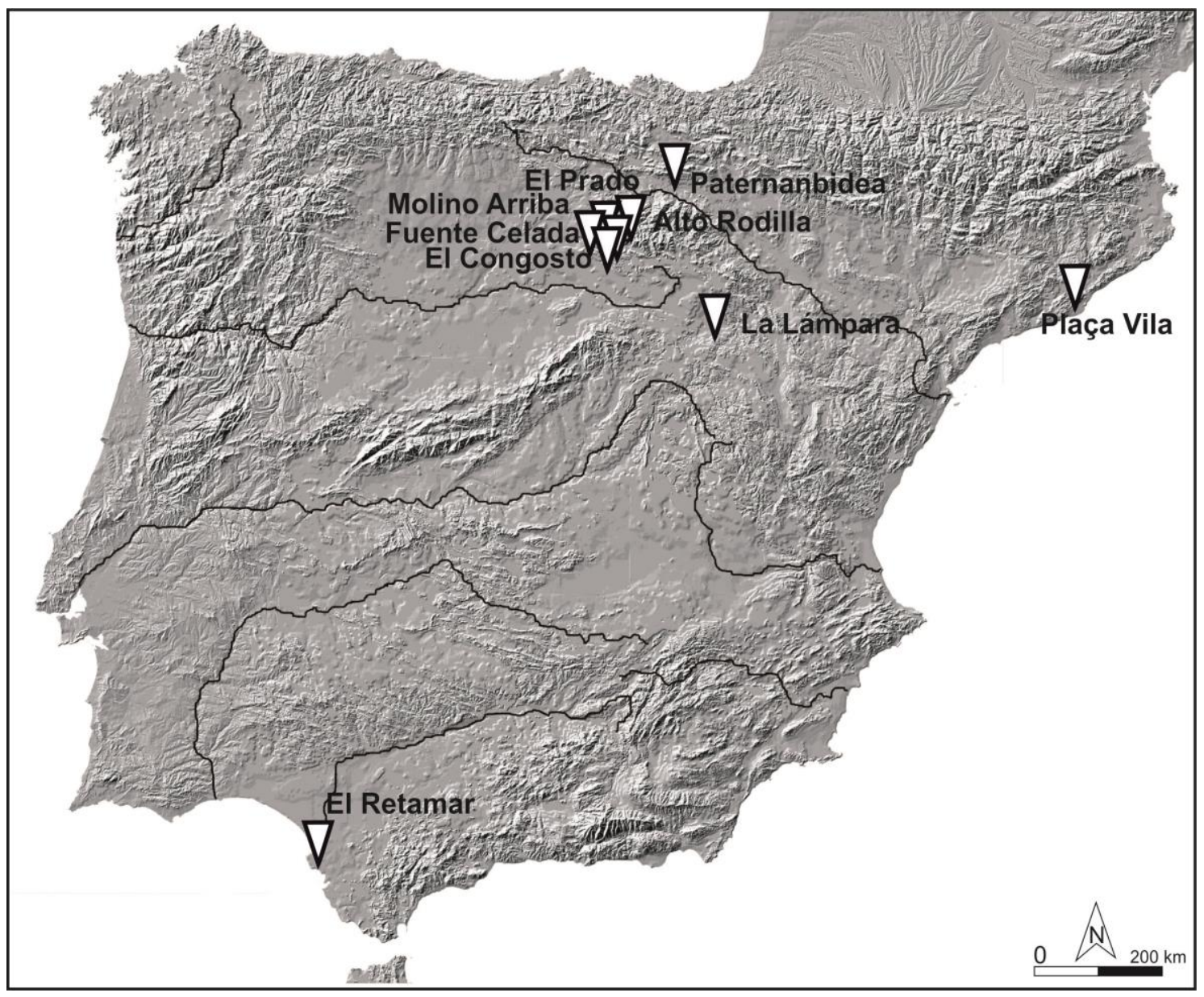


Fig. 14. Burials detected in open-air Early Neolithic settlements of the Iberian Peninsula.

Therefore, we propose that the essential organizational base of the first Neolithic communities in this territory was the domestic group, composed of a small number of individuals, probably families (Bate and Terrazas 2002), comprising households, with one or more dwelling structures. These would be surrounded by diverse productionconsumption areas, e.g. combustion structures, artifacts-fabrication areas, raw-materials sites, waste or storage areas, and, in some cases, isolated burials (Fig. 14). In numerous cases, they contain single or double tombs of men, adult women, men of different ages or children, accompanied by very different non-standardized burial goods, although in many cases these include work instruments. Nevertheless, the evidence documented in many of the settlements mentioned above are only a part of their overall activities and spaces corresponding to a domestic unit and not preserved.

Besides, archaeological evidence characterizes the first Neolithic societies by a dispersed settlement pattern (Bernabeu et al. 2008; Alonso-Fernández and JiménezEcheverría 2014), throughout valley floors with occasional aggregation of households, creating primordial villages. Farms presumably acted as self-sufficient units, based on kinship bonds. Domestic groups imply overarching social units, probably determined filially (Alonso-Fernández 2017). In this sense, the first palaeogenetic studies (Olalde et al. 2017) and mobility patterns (Ortega et al. 2017), accompanied by the analysis of funerary ritual, allow us to infer aspects of the social structure. The fact that the practice of individual burials is recurrent, in several cases of elderly women, with manipulations of corpses, suggests a social system based on matrilineality, where heads of family or 
lineage would be revered socially by being buried in significant places (AlonsoFernández and Jiménez-Echeverría 2017: 192). These filial groups appear to be the largest social units in which production and reproduction would be organized (Bate and Terrazas 2002). Similarities in the material culture documented at different early Neolithic settlements reflect such links. One of the best examples is the repetition in forms and decoration in Cardial Ware ceramics, produced independently in each household (McClure 2011), with schematic designs as well as on rock art at several sites (Martí and Hernández 1988). According to research in the areas around Valencia, the so-called Or-Cendres Cardial Ware group (Fig. 15) provides evidence of a dispersed settlement pattern, mainly in farms. From these farms, an integral management of territories would be practiced, with the full use of caves. Caves were used presumably for funerary practices, storage, shelter, penning, or even as ritual spaces with a special significance for the community. This latter function has been proposed for Cova de l'Or (Martí and Hernández 1988; Martí et al. 2001; García Borja et al. 2004). All these domestic groups apparently shared varied cultural and ideological manifestations, notably macroschematic art and old schematic art (Torregrosa 2000; Hernández, 2016). These artistic manifestations appear not only on the surfaces of Cardial Ware ceramic vessels, but also in rock art. All such evidence points to a tribal society (García and Jover 2011; García 2012). 


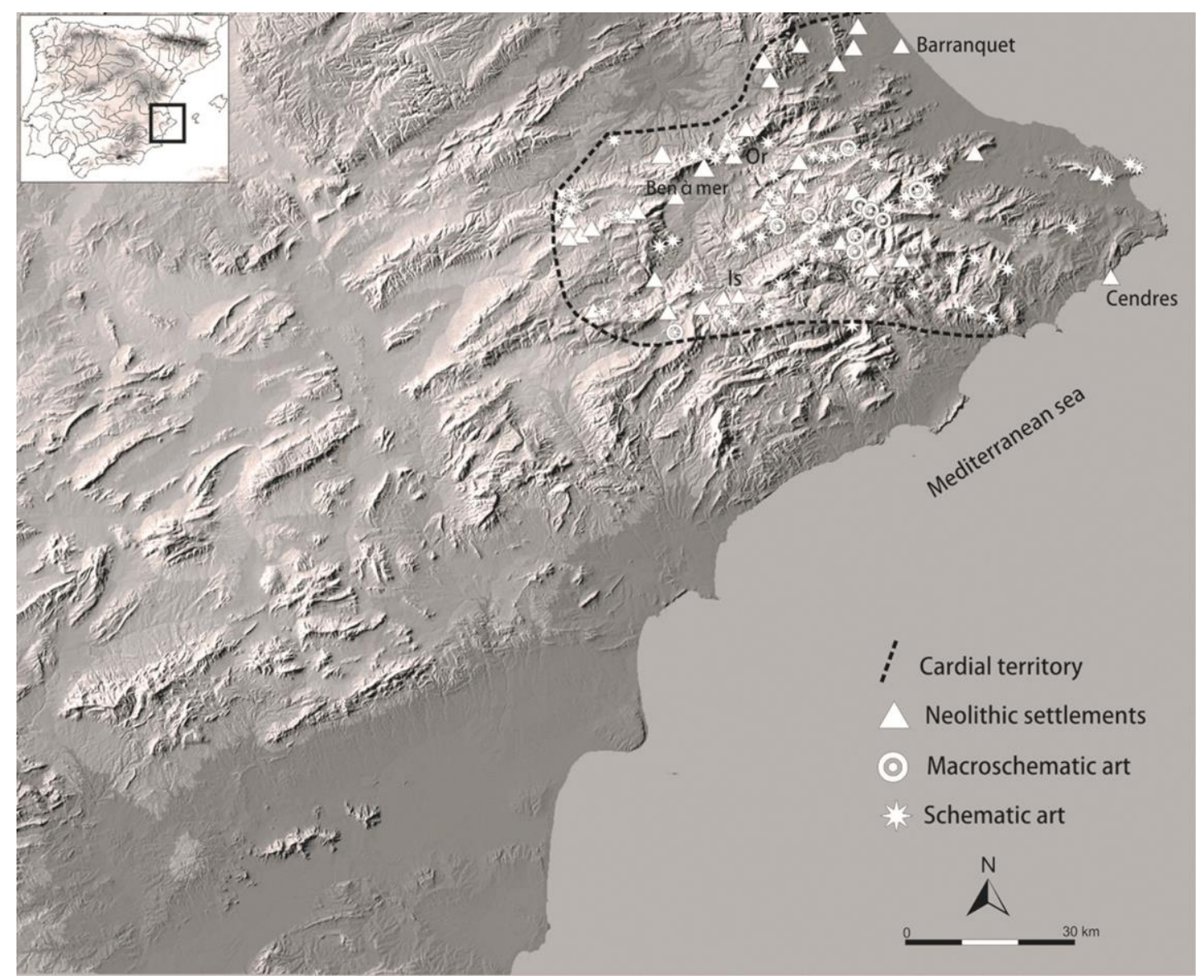

Fig.15. Map representing the archaeological features that characterize the Or-Cendres

Cardial Ware group: spatial distribution of Cardial sites, macroschematic art and schematic art in the southern Valencian region.

\section{Conclusions}

In this article we seek to recognize the spatial and social organization of the first Neolithic communities in the Iberian Peninsula. Our analysis of the archaeological record shown highlights several important aspects:

1. The excavations and analyses of cave sites over several decades have enabled the definition of the first Neolithic groups on the area, defining their chronology, characterizing their materiality, and establishing the sequence of their development. 
However, these studies have not permitted a fuller knowledge either of their territorial management or their social organization. The data compiled from caves is not the best source to analyze the organization of Neolithic households.

2. Open-air Neolithic sites until recently could not be characterized, due to the constraints of the extensive open-area excavation required and the partial degree of preservation of the material remains. In fact, to date, many of the structures have been defined merely as isolated evidence and only in a few cases as settlements.

3. In recent years, the development of research projects and, mainly, the activity of rescue archaeology have enabled the excavation and study of large open-area surfaces. With a suitable theoretical framework, deciphering a partial archaeological record is possible, allowing the recognition of the spatial organization within the first farming domestic groups in the study area. This analysis indicates that the basic social organization unit was the farm-type household, characterized by one or more structures and surrounded by different clearly organized production/consumption areas (Fig. 16). The first settlement processes of these farming groups presumably gave rise to aggregations of households that perhaps developed into minor settlements. 


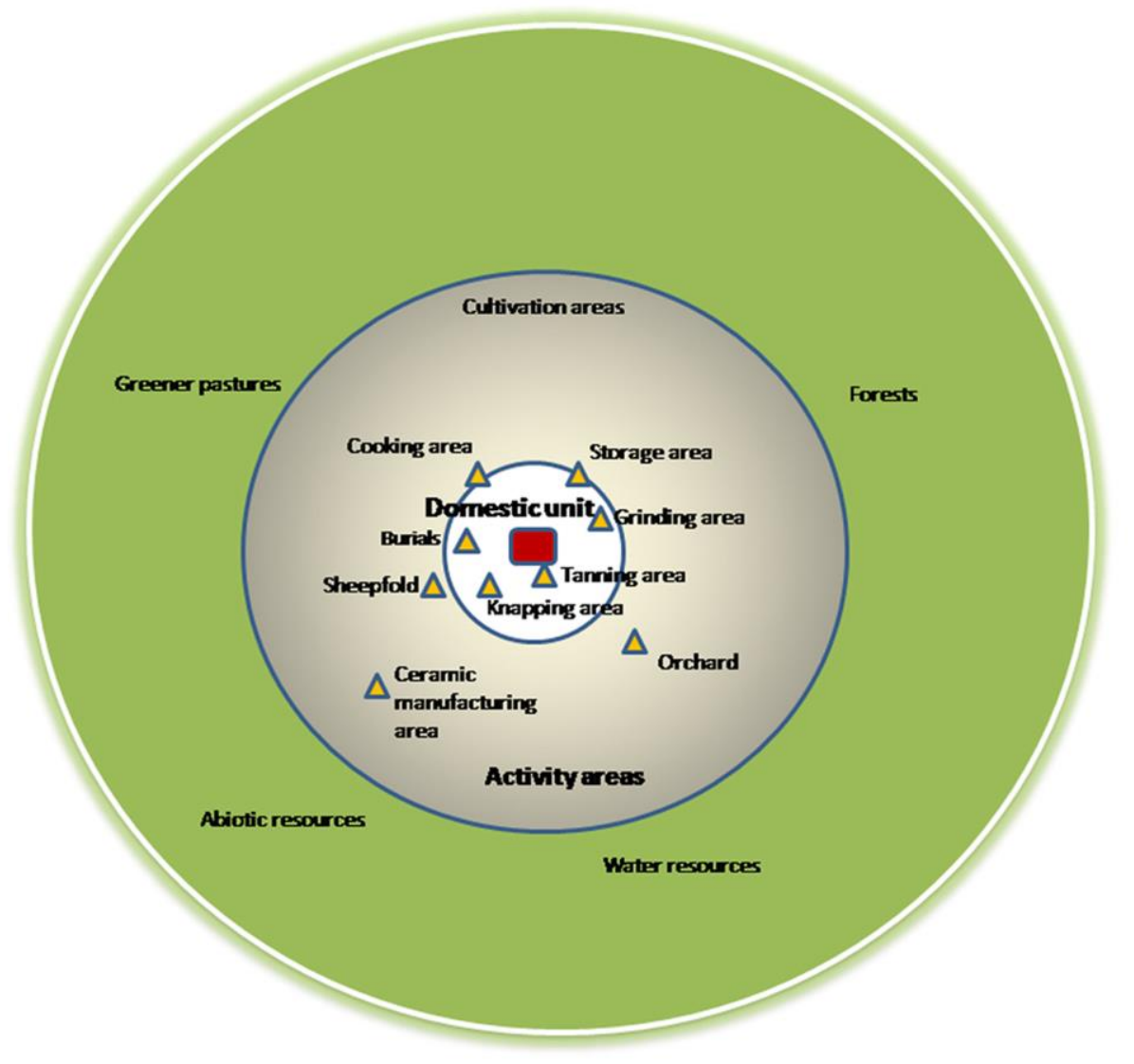

Fig. 16. Theoretical diagram proposing the spatial organization of activities areas in an Early Neolithic household.

Nevertheless, in the research on this area, several constraints need to be taken into account. First, it is critical to consider the different natural and human shifts in the physical environment that rendered the archaeological evidence of Neolithic households and, thus the subsequent differing levels of quality in the archaeological data. The great majority of the study sites for this period in the Iberian Peninsula have undergone alterations. Situated on fluvial terraces, they were disturbed by diverse post-depositional processes. The recurrent occupation and agricultural exploitation of the same spaces throughout history is the main destructive cause of many of the earliest Neolithic settlements (Torregrosa et al. 2011). In addition, the dwellings and activity spaces, 
involving organic materials, have been poorly preserved in their original environmental contexts, the remains being fragmented and altered.

Furthermore, several key factors in studying these early Neolithic societies relate to our own interpretations of the social organization of past human groups. At an archaeological site, the evidence can be varied, from a single activity area, to different dwelling structures. Also, not all the archaeological sites are settlements. A settlement entails a set of labor processes related to the temporary or permanent dwelling of a specific human group in a specific area, fulfilling their needs in production, reproduction and maintenance (Montón and Sánchez-Romero 2008). In the present case, the household of at least one dwelling, with evidence of different activities, has been identified only at sites such as Los Cascajos, El Prado, Benàmer II or Mas d'Is, where areas of at least $1800 \mathrm{~m}^{2}$ were excavated. These examples induce us to interpret possible households at other sites within smaller excavated areas and thus where archaeological evidence is more limited. The excavation of open-air surfaces large enough to allow inferences concerning households -a minimum of 2000/3000 $\mathrm{m}^{2}$, should be a primary criterion in future excavation strategies.

If we wish to deepen our knowledge of domestic units and, by extension, of the productive and reproductive organization of the first Neolithic groups in the Iberian Peninsula, we will have to adopt research strategies that involve excavating new sites in open-air areas, over very wide stretches, which, based on this study, should have a surface of at least $3000 \mathrm{~m}^{2}$. Otherwise, we will continue to document partial structures or areas of activity that are difficult to interpret accurately in their context.

\section{Acknowledgements}


We thank Martin Locker and David Nesbitt for the revision of this text.

This work was developed inside the Research Group in Prehistory and Protohistory of the University of Alicante (VIGROB-098) and the research project "Espacios sociales y espacios de frontera durante el Calcolítico y la Edad del Bronce en el Levante de la península ibérica" (HAR2016-76586-P). 


\section{Authors Biography}

Dr. Francisco Javier Jover Maestre is a Senior Lecturer in the Department of Prehistory, Archaeology, Ancient History, Greek and Latin and a researcher at the University Institute of Research in Archaeology and Heritage (INAPH), at the University of Alicante. His research focuses on the study of the historical process from the VI to the II millennium BC in the Eastern Iberian Peninsula.

María Pastor Quiles is a Pre-doctoral researcher holding a FPU Fellowship from the Spanish Ministry of Education at the Department of Prehistory, Archaeology, Ancient History, Greek and Latin at the University of Alicante. Her research focuses on the study of prehistoric building techniques and materials in the Eastern Iberian Peninsula.

Dr. Palmira Torregrosa Giménez is an Associate Lecturer in the Department of Prehistory, Archaeology, Ancient History, Greek and Latin and a researcher at the University Institute of Research in Archaeology and Heritage (INAPH), at the University of Alicante. Her research is based on the study of Prehistoric rock art and the Neolithic period in the Eastern Iberian Peninsula. 


\section{References}

Acosta, G. 1999. "Procesos de trabajo determinado. La configuración de modos de trabajo en la cultura arqueológica”. Boletín de Antropología Americana 35: 5-21.

Allison, P. M. 1999. The archaeology of household activities. London and New York: Routledge.

Alonso-Fernández, C. (ed.). 2017: Vida y muerte en el asentamiento del Neolítico Antiguo de El Prado (Pancorbo, Burgos). Construyendo el Neolítico en la Península Ibérica. BAR International Series 2876. Oxford: BAR Publishing.

Alonso-Fernández, C. and Jiménez-Echevarría, J. 2014: “Contribución al estudio del poblamiento, modos de vida y ritual funerario del neolítico antiguo: el asentamiento al aire libre de El Prado (Pancorbo, Burgos)". Zephyrus, LXXIV: 41-64.

Alonso-Fernández, C. and Jiménez-Echeverría, J. 2015: "El neolítico en el corredor Alto EbroAlto Duero: dos hallazgos funerarios del Neolítico antiguo y reciente en el Monasterio de Rodilla (Burgos)”. In Gonçalves, V.S., M. Diniz and A. Catarina Sousa (Eds.): $5^{\circ}$ Congresso do Neolítico peninsular, Estudos and memorias, 8, Centro de Arqueologia da Universidade de Lisboa, Lisboa: 540-546.

Alonso-Fernández, C. and Jiménez-Echeverría, J. 2017: “Una visión global del yacimiento arqueológico El Prado en el contexto del Neolítico interior de la Península Ibérica”. In Alonso-Fernández, C.: Vida y muerte en el asentamiento del Neolítico Antiguo de El Prado (Pancorbo, Burgos). Construyendo el Neolítico en la Península Ibérica. BAR International Series 2876. Oxford: BAR Publishing: 189-196. 
Ammerman, A. J., G. Shaffer and N. Hartmann. 1988. “A Neolithic household at Piana di Curinga, Italy”. Journal of Field Archaeology 15: 121-140.

Antolín, F. 2015: "Entre agricultores primitivos, cultivo de rozas y pastores transhumantes. Una mirada crítica a los modelos económicos propuestos para los grupos neolíticos del noreste peninsular y una aportación desde el registro carpológico". Revista d'Arqueologia de Ponent, 25, 11-45.

Arias, P., Cerrillo, E., Jackes, M. and Lubell, D. 2015: "Veguillas (Cáceres): un nuevo núcleo de poblamiento neolítico en el interior de la península Ibérica”. In Gonçalves, V.S., M. Diniz and A. Catarina Sousa (Eds.): $5^{\circ}$ Congresso do Neolítico peninsular, Estudos and memorias, 8, Centro de Arqueologia da Universidade de Lisboa, Lisboa: 208-217.

Artigues, P. Ll., P. Bravo and E. Hinojo. 2007. "Excavacions arqueològiques a Can Gambús 2, Sabadell (Vallés Occidental)”. Tribuna d'Arqueologia 2006, 111-140.

Aura, J.E,, J. F. Jordá, P. García, O. García, E. Badal, M. Pérez Ripoll, G. Pérez Jordà, J. L. Pascual, Y. Carrión, J. V. Morales. 2013. “Una perspectiva mediterránea sobre el proceso de neolitización. Los datos de la cueva de Nerja en el contexto de Andalucía (España)". Menga: Revista de Prehistoria de Andalucía 4: 53-78.

Badal, E. 1999: "El potencial pecuario de la vegetación mediterránea: las cuevas redil". Saguntum, extra 2, 69-76.

Badal, E., B. Martí and M. Pérez Ripoll 2012. "From agricultural to pastoral use: changes in Neolithic landscape at Cova de 1'Or (Alicante, Spain)". Wood and charcoal. Evidence for human and natural History. Saguntum, extra 13, 13-24.

Baldellou, V., and J. Mestres. 1981. "Les Guixeres de Vilobí, un hábitat del neolític antic a l'aire 1liure". In Institut de Prehistòria i Arqueologia de Barcelona, El Neolític a 
Catalunya. Taula Rodona de Montserrat 1980. Montserrat: Publicacions de l'Abadia de Montserrat, 69-74.

Banning, E.B. and B.F. Byrd. 1987. "Houses and the changing residential unit: domestic architecture at PPNB 'Ain Ghazal, Jordan”. Proceedings of the Prehistoric Society, vol. 53: $309-325$.

Banning, E.B. and M. Chazan. 2006. Domesticating Space: Construction, Community and Cosmology in the late Prehistoric Near East. Berlin 'ex Oriente (SENEPSE 12).

Bate, L. F. 1998. El proceso de investigación en arqueología. Barcelona: Crítica.

Bate, L.F., and A. Terrazas. 2002. "Sobre el modo de reproducción en sociedades pretribales". Revista Atlántica-Mediterránea de Prehistoria y Arqueología Social V: 11-41.

Beaudry, M. C. 2015. "Households beyond the house: On the Archaeology and Materiality of Historical Households”. In Fogle, K.R., J.A. Nyman M.C and Beaudry, Beyond the walls: new perspectives on the Archaeology of historical Households. Gainesville: University Press of Florida.

Beeching, A. and I. Sénépart. 2009. De le maison au Village. L’habitat néolithique dans le sud de la France et le Nord-ouest méditerránean. Actes de la table-ronde de la Société Préhistorique Française, Mémoire XLVIII. Marseille: Société Préhistorique Française.

Bernabeu, J. and B. Martí. 2012. "Región central del Mediterráneo". In Rojo, M.A., R. Garrido and I. Martínez de Lagrán, El Neolítico en la península Ibérica y su contexto europeo. Madrid: Cátedra, 371-403. 
Bernabeu, J. and B. Martí. 2014. "The first agricultural groups in the Iberian Peninsula". In Manen C., T. Perrin and J. Guilaine, La transition néolitique en Méditerranée. Paris: Errance-Arts Editions, 419-438.

Bernabeu, J., Ll. Molina, M.A. Esquembre, J.R. Ortega and J. D. Boronat. 2009. "La cerámica impresa mediterránea en el origen del Neolítico de la península Ibérica”. In De Méditerranée et d'ailleurs. Mélanges offerts à Jean Guilaine. Toulouse: Archives d'Écologie Préhistorique, 83-95.

Bernabeu J., Ll. Molina, T. Orozco and A. Diez 2008. "Early neolithic at the Serpis Valley, Alicante, Spain". In Diniz, M. The early Neolithic in the Iberian Peninsula. Regional and transregional components, British Archaeological Reports International Series 1857. Oxford: Archaeopress, 53-59.

Bernabeu, J., T. Orozco, A. Diez, M. Gómez and F.J. Molina. 2003. "Mas d'Is (Penàguila, Alicante). Aldeas y recintos monumentales del Neolítico Inicial en el valle del Serpis”. Trabajos de Prehistoria 60-2: 39-59.

Blanton, R. 1994. Houses and Households: A Comparative Study. New York: Plenum.

Bordas, A., R. Mora and V. López. 1996. "El asentamiento al aire libre del Neolítico antiguo en la Font del Ros (Berga, Berguedà)". Rubricatum I: 397-406.

Borrell, F. and J. F. Gibaja. 2012. "The first neolithic communities in northeast Iberia: procurament, production, and use of lithic tools at the settlement of Caserna de Sant Pau del Camp (Barcelona, Spain)”. The Journal of Island and Coastal Archaeology 7-3: 313-337.

Bosch, J., J. Chinchilla and, J. Tarrús. 2000. El poblat lacustre del neolític antic de La Draga. Excavacions de 1900 a 1998. Monografíes del Centre d'Arqueologia Subaquàtica de 
Catalunya 2. Girona: Museu d'Arqueologia de Catalunya-Centre d'Arqueologia Subaquàtica de Catalunya.

Bosch, J., J. Chinchilla and, J. Tarrús. 2006. Els objectes de fusta del poblat neolític de La Draga. Excavacions de 1995-2005. Monografíes del Centre d'Arqueologia Subaquàtica de Catalunya 6. Girona: Museu d'Arqueologia de Catalunya-Centre d'Arqueologia Subaquàtica de Catalunya.

Bosch, J., J. Chinchilla and J. Tarrús. 2011. El poblat lacustre del neolític antic de La Draga. Excavacions 2000-2005. Monografíes del Centre d'Arqueologia Subaquàtica de Catalunya 9. Museu d'Arqueologia de Catalunya-Centre d'Arqueologia Subaquàtica de Catalunya. Girona.

Bosch, J., A. Forcadell and $\mathrm{M}^{\mathrm{a}}$ M. Villalbi. 1996. "El Barranc de Fabra: asentamiento de inicios del IV milenio aC en el curso inferior del Ebro". Rubricatum: revista del Museu de Gavà No 1-1: 391-396.

Camalich, M. D. and D. Martín. 2013. "Los inicios del Neolítico en Andalucía. Entre la tradición y la innovación”. Menga 04: 103-129.

Carballo, D. M. 2011. "Advances in the Household Archaeology of Highland Mesoamerica". Journal of Archaeological Research 19: 133-189.

Cardoso, J.L. 2015. “A Estação do Neolitido Antigo do Carrascal (Oeiras, Lisboa, Portugal)”. In Goçalves, V.S., M Diniz and A. C. Sousa (ed). $5^{\circ}$ Congresso do Neolitico peninsular. Studos y Memórias 8. Centro de Arqueologia da Universidade de Lisboa: 159-168.

Carvalho, A.F. 2008. A Neolitizaçao do Portugal Meridional. Os exemplos do Maciço Calcário Estremenho e do Algarve Ocidental. Promontoria Monográfica 12. Universidade do Algarve. 
Carvalho, A.F. 2012. “Portugal”. In Rojo, M.A., R. Garrido, I. García-Martínez de Lagrán. El neolítico en la Península Ibérica y su contexto europeo, Cátedra: 175-212.

Carvalho, A.F. 2015. "A two-stage economic succession at the inception of farming in central Portugal. Preliminary examination of possible causes and consequences". Vegueta: Anuario de la Facultad de Geografía e Historia, №. 15: 89-109

Castro, P. V., N. Escanilla, T. Escoriza, J. Oltra and T. Sarkis. 2013. "Domestic units, definition and multiform archaeological appearance. Economy and politics in unlike domestic prehistoric groups of the western Mediterranean”. In Madella, M., G. Kovács, B. Berzsényi and I. Brizi Godino. Archaeology of household. Oxford and Oakville: Oxbow Books, 86-111.

Cavulli, F. 2008. Abitare il Neolitico: Le piu antiche structture antropiche del Neolitico in Italia settentrionale. Preistoria Alpina 43. Trento: Museo tridentino di Scienze Naturali.

Cerrillo, E. 2006. Los Barruecos: primeros resultados sobre el poblamiento neolítico de la cuenca Extremeña del Tajo. Memorias de Arqueología Extremeña. Mérida.

Cerrillo, E., and J. A. López Sáez. 2012. “Extremadura”. In Rojo, M. Á., R. Garrido, I. GarcíaMartínez de Lagrán: El neolítico en la Península Ibérica y su contexto europeo, Madrid: 543-580.

Costa, F., P. García, R. Marcet and J. Mas. 1982. El jaciment a l'aire lliure de Can Soldevila, Can Banús i Sàlcies. Santa Perpètua de la Mogoda: Fulls d'Arqueologia i Prehistòria de Santa Perpètua de la Mogoda.

Diniz, M. (ed.) 2008. Early Neolithic in Iberian Peninsula. Regional and Transregional Components. XV UISPP World Congress (Lisbon, September 2006). Oxford: BAR International Series; 1857. 
Douglass, J. G., N. Gonlin. 2012. The Household as Analytical Unit: Case Studies from the Americas. In Ancient Household of the Americas: Conceptualizing What Households Do. Ed by John G. Douglass and Nancy Gonlin Boulder: University Press of Colorado: $1-46$.

Esquembre, M.A., J.D. Boronat, F.J. Jover, A. Luján, J. Fernández, R. Martínez, P. Iborra, C. Ferrer, R. Ruiz and J.R. Ortega. 2008. "El yacimiento neolítico de El Barranquet de Oliva (Valencia)”. In Hernández, M.S., J. A. Soler and J. A. López: IV Congreso del Neolítico Peninsular, Alicante: 183-190.

Esteve, X., P. Martín, F.X. Oms, R. Jornet and D. López. 2012. "Intervencions arqueològiques als enllaços de l'autopista AP-7 de Vilafranca del Penedés: nous assentaments prehistòrics a l'aire lliure al Penedés". Tribuna d'Arqueologia 2010-2011, 23-39.

Fernández-Crespo, T. and R. J. Schulting 2017: "Reconstrucción de la dieta de los individuos neolíticos antiguos inhumados en El Prado (Pancorbo, Burgos) a través del análisis de isótopos estables de carbono y nitrógeno sobre colágeno óseo”. In Alonso-Fernández, C.: Vida y muerte en el asentamiento del Neolítico Antiguo de El Prado (Pancorbo, Burgos). Construyendo el Neolítico en la Península Ibérica. BAR International Series 2876. Oxford: BAR Publishing: 123-134.

Flannery, K. and M. Winter. 1976. “Analyzing household activities”. In Flannery, K. The early Mesoamerican Village. Studies in Archaeology 34-44. New York: Academia Press.

Fontanals, M., I. Euba, J.I. Morales, F. X. Oms and J. M. Vergés. 2008. “El asentamiento litoral al aire libre de El Cavet (Cambrils, Tarragona)". In Hernández, M.S., J.A. Soler and J.A. López, IV Congreso del Neolítico de la península Ibérica. Tomo I. Alicante: Museo Arqueológico Provincial de Alicante, 168-175. 
Fortó, A., P. Martínez and V. Muñoz. 2008: "Las estructuras de combustión de grandes dimensiones de Ca l'Estrada en el Neolítico europeo". In Hernández, M.S., J.A. Soler and J.A. López, IV Congreso del Neolítico de la península Ibérica. Tomo I. Alicante: Museo Arqueológico Provincial de Alicante, 306-314.

Flores, J.A. 2007. Patrón de asentamiento e inferencia social. Una propuesta metodológica para la construcción de inferencias sociales. México: Instituto Nacional de Antropología e Historia.

Flors, E. 2009. Torre la Sal (Ribera de Cabanes, Castellón). Evolución del paisaje antrópico desde la Prehistoria hasta el Medievo. Monografies de Prehistòria i Arqueologia Castellonenques 8. Castelló.

Frère-Sautot, M.C. 2003. Le feu domestique et ses structures au Néolithique et à l'Age des Métaux. Actes du colloque de Beaune et Bourg-en-Bresse, 7-8 octobre 2000. Collection Préhistoire, 9. Montagnac: M. Mergoil.

Fugazzola, M. A., D'Eugenio, G., Pessina, A. 1993. "La Marmotta (Anguillara Sabazia, R.M.). Scavi 1989. Un abitato perilacustre di età neolitica". Bulletino di Paletnologia italiana 84, H: 181-342.

García Atiénzar, G. 2010: "Las comarcas centromeridionales valencianas en el contexto de la neolitización de la fachada noroccidental del Mediterráneo". Trabajos de Prehistoria 67, 1, 37-58.

García Atiénzar, G. 2012. "Las sociedades tribales durante el neolítico inicial en el Mediterráneo occidental: procesos de expansión and consolidación durante el VI milenio cal BC". Boletín de Antropología Americana 47: 101-119. 
García, G. and F. J. Jover. 2011. "The introduction of the first farming communities in the western Mediterranean: the valencian region in Spain as example". Arqueología Iberoamericana 10: 17-29.

García, G., F. J Jover, C. Ibáñez, C. Navarro and D. Andrés. 2006. "El yacimiento neolítico de la calle Colón (Novelda, Alicante)", Recerques del Museu d’Alcoi 15: 19-28.

García Borja, P., I. M., Domingo, C., Roldán, C., Verdasco, J., Ferrero, P., Jardín, J. Bernabeu. 2004. “Aproximación al uso de la materia colorante en Cova de l'Or" Recerques del Museu d'Alcoi, 13: 35-52.

García Gazólaz, J. and J. Sesma. 2007. "Enterramientos en el poblado neolítico de Los Cascajos (Los Arcos)”. In Hurtado, M.A., F. Cañada, J. Sesma and García, J: La Tierra te sea leve. Arqueología de la muerte en Navarra. Pamplona: 52-58.

García Gazólaz, J., J. Sesma, M.A. Rojo, A. Alday, R. Garrido, I. García. 2011. “Los Cascajos (Los Arcos, Navarra)". In Bernabeu, J., M.A. Rojo ando Ll. Molina (coord.): Las primeras producciones cerámicas: el VI milenio cal AC en la península Ibérica. Saguntum extra 12. Valencia: 135-140.

García Puchol, O., A. Díez and S. Pardo-Gordó 2016: "Radiocarbono y neolitización en la Península Ibérica”. Del Neolític a l'Edat del Bronze en el Mediterrani occidental. Estudis en homenatge a Bernat Martí Oliver. TV SIP 119. Valencia: 61-73.

García Puchol, O., J. Bernabeu-Aubán, C. Michael Barton and S. Pardo-Gordó 2018: “A Bayesian Approach for Timing the Neolithization in Mediterranean Iberia". Radiocarbon 60,1, 181-205.

Gillespie, S.D. 2012: "el modelo de sociedad de "casas" en la arqueología de la vida cotidiana. El caso de Chalcatzingo, Morelos”. In Acosta, G. (Ed.), Espacios domésticos y áreas de 
actividad en el México antiguo y otras zonas culturales. VII Coloquio Pedro Bosch Gimpera: 21-48. UNAM-IIA. México.

Gonçalvez, V.S. and Catarina Sousa, A. 2015: "O sitio do Neolitico antigo de Casas Novas (Coruche). Leituras preliminares”. In Gonçalves, V.S., M. Diniz and A. Catarina Sousa (Eds.): $5^{\circ}$ Congresso do Neolítico peninsular, Estudos and memorias, 8, Centro de Arqueologia da Universidade de Lisboa, Lisboa: 236-255.

Goñi, A., E. Chávez, M.D. Camalich, D. Martín and P. González. 2002. "Intervención arqueológica de urgencia en el poblado de Cabecicos Negros (Vera, Almería)". Actuaciones arqueológicas de urgencia, vol I. Anuario Arqueológico de Andalucía/2000. Junta de Andalucía: 73-86.

Goufa, E. and F.R. Correia. 2016. "The Early and Middle Neolithic from Algarve (Portugal): the current state-of-art and its geographical distribution". VI Congreso del Neolítico en la Península Ibérica. Póster. Granada

Guilaine, J. and G. Cremonesi. 2003. Torre Sabea: un établissement du Néolithique ancien en Salento. Roma: École française de Roma.

Guilaine, J., C. Manen and J.D. Vignè. 2007. Pont de Roque-Haute. Noveaux regards sur la neolithisation de la France Méditerranéene. Toulouse: Archives d'Écologie Préhistorique-Societé Préhistorique Française.

Hendon, J. A. 2007. "Living and working at home: the social archaeology of household production and social relations". In Meskell, L. and R. W. Preucel, A Companion to Social Archaeology. Oxford: Blackwell, 272-286.

Hernández, M. S. 2016. “Arte Macroesquemático vs. Arte Esquemático. Reflexiones en torno a una relación intuida". In Del neolític a l'edat del bronze en el Mediterrani occidental. 
Estudis en homenatge a Bernat Martí Oliver. Trabajos Varios del Servicio de Investigación Prehistórica de Valencia 119. Valencia: Diputación Provincial de Valencia, 481-490.

Hirth, K.G. 1993: "The household analytical unit. Problems and Theory”. In Stanley, R.S. and Hirth, K.G. (Ed.). Prehispanic dynastic units in Western Mesoamerica. Studies of households, compounds and residence: 21-36. Boca Raton.

Hirth, K.G. (2012): "Craft Production and the Domestic economy in Mesoamerica”. In Acosta, G. (Ed.), Espacios domésticos y áreas de actividad en el México antiguo y otras zonas culturales. VII Coloquio Pedro Bosch Gimpera: 49-85. UNAM-IIA. México.

Hofmann, D. 2012. "La interpretación de la arquitectura doméstica del Neolítico en Europa”. In Rojo, M.A., R. Garrido and I. Martínez de Lagrán, El Neolítico en la península Ibérica y su contexto europeo. Madrid: Cátedra, 41-54.

Isern, N., J. Fort, A.F. Carvalho, J. F. Gibaja, and J. J. Ibáñez. 2014. “The Neolithic transition in the Iberian Peninsula: data analysis and modeling”. Journal of Archaeological Method and Theory 21: 447-460.

Jiménez, J., J.M. Rojas, G. Garrido and J. Perera. 2008. "El yacimiento del Neolítico inicial de La Paleta (Numancia de la Sagra, Toledo)”. In Hernández, M.S., J.A. Soler and J.A. López: IV Congreso del Neolítico peninsular. Alicante: 126-136.

Jiménez, J. 2010. Cazadores y campesinos. La neolitización del interior de la Península Ibérica. Real Academia de la Historia. Madrid: Bibliotheca Archaeologica Hispana, 31.

Jiménez-Echeverría, J. 2017a: "Cronología absoluta del registro arqueológico de El Prado”. In Alonso-Fernández, C.: Vida y muerte en el asentamiento del Neolítico Antiguo de El 
Prado (Pancorbo, Burgos). Construyendo el Neolítico en la Península Ibérica. BAR International Series 2876. Oxford: BAR Publishing: 27-38.

Jiménez-Echeverría, J. 2017b: "La organización espacial de El Prado: ocupación, espacios de uso y fase de abandono". In Alonso-Fernández, C.: Vida y muerte en el asentamiento del Neolítico Antiguo de El Prado (Pancorbo, Burgos). Construyendo el Neolítico en la Península Ibérica. BAR International Series 2876. Oxford: BAR Publishing: 39-48.

Jover, F. J. 2011. “El proceso histórico del VII al IV milenio cal BC en las tierras meridionales valencianas: algunas inferencias a partir de la documentación arqueológica de Benàmer". In Torregrosa, P., Jover, F. J. and López, E., dirs., Benàmer (Muro de l'Alcoi, Alicante). Mesolíticos y neolíticos en las tierras meridionales valencianas. Valencia: Trabajos Varios del SIP, 112, Diputación Provincial, 341-358.

Jover, F. J. 2013. "Las áreas de actividad y las unidades domésticas como unidades de observación de lo social: de las sociedades cazadoras-recolectoras a las agricultoras en el este de la península ibérica”. In Gutiérrez, S. and I. Grau, De la estructura doméstica al espacio social. Lecturas arqueológicas del uso social del espacio. Alicante: Universidad de Alicante, 13-38.

Kadowak, S. 2012. "A household perspective towards the Pre-Pottery Neolithic to Late Neolithic cultural transformation in the Southern Levant”. Orient 47: 3-28.

Laslett, P. 1972. "Introduction: The history of the family". In Laslett, P. and R. Wall, Household and family in the past time. Cambridge: Cambridge University Press, 1-89.

Lazarich, M. and J. Ramos. 2002. El asentamiento de "El Retamar" (Puerto Real, Cádiz): contribución al estudio de la formación social tribal y a los inicios de la economía de producción en la Bahía de Cádiz. Universidad de Cádiz: Servicio de Publicaciones. 
Lazarich, M., J. Ramos, V. Castañeda, C. Blanes, M. Montañés, N. Herrero, M. Pérez, J.M. Lozano, E. García, S. Aguilar and M. Núñez. 1999. “Excavación de urgencia en el asentamiento de El Retamar (Puerto Real, Cádiz). Informe preliminar. III Actividades de Urgencia. Anuario Arqueológico de Andalucia-1995. Sevilla: 67-73.

Lazúen, T. and J. González-Urquijo 2017: "Functional Analysis of Chipped Stone Tools from the Neolithic Open Air Site of El Prado”. In Alonso-Fernández, C.: Vida y muerte en el asentamiento del Neolítico Antiguo de El Prado (Pancorbo, Burgos). Construyendo el Neolítico en la Península Ibérica. BAR International Series 2876. Oxford: BAR Publishing: 67-78.

López Aguilar, F. 1990. Elementos para una construcción teórica en arqueología. Colección científica 191. México: Instituto Nacional de Antropología e Historia.

López Sáez, J. A., Pérez, S., Alba, F. 2011. "Estudios sobre evolución del paisaje: Palinología”. In Torregrosa, P., F. J. Jover and E. López, dirs., Benàmer (Muro del'Alcoi, Alicante), Mesolíticos y neolíticos en las tierras meridionales valencianas, Valencia: Serie Trabajos Varios del SIP, 112, Diputación Provincial de Valencia, 107-111.

Madella, M., G. Kovács, B. Berzsényi and I. Briz I Godino. 2013. Archaeology of household. Oxford and Oakville: Oxbow Books.

Manzanilla, L. 1986. “Introducción”. In Manzanilla, L. Unidades habitacionales mesoamericanas y sus áreas de actividad. México: Instituto de Investigaciones Antropológicas-Universidad Autónoma de México, 9-18.

Márquez-Romero, J. E. and V. Jiménez-Jáimez. 2014. "Space and Time in the Architecture of Prehistoric Enclosures. The Iberian Peninsula as a case study". In Souvatzi, E. and A. 
Hadji, Space and Time in Mediterranean Prehistory. London and New York: Routledge, 214-230.

Martí, B. and M.S. Hernández. 1988. El Neolític valencià. Art rupestre i cultura material. Servicio de Investigación Prehistórica del Museo de Prehistoria de Valencia. Valencia: Diputación Provincial de Valencia.

Martí, B., A. Arias-Gago, R. Martínez, J. Juan-Cabanilles. 2001. "Los tubos de hueso de la Cova de L'Or (Beniarrés, Alicante). Instrumentos musicales en el Neolítico Antiguo de la Península Ibérica”. Trabajos de Prehistoria 58 (2): 41-67.

Martín Colliga, A. 1992. "Lectura de la distribució i caracterització dels jacimients cardials. Estat de la investigación sobre el Neolític a Catalunya”. In IX Col.loqui internacional d'arqueologia de Puigcerdà. Puigcerdà i Andorra 1991. Puigcerdà: Institut d'Estudis Ceretans, 68-71.

Martín-Socas, D., M.D. Camalich, J.L. Caro and F.J. Rodríguez. 2017. "The beginning of the Neolithic in Andalusia". Quaternary International XXX: 1-21.

Martínez Sánchez, R. M. 2015: “La Casa del Tabaco (El Carpio, Córdoba). Un establecimiento neolítico en el interior de un meandro del Guadalquivir”. In Gonçalves, V.S., M. Diniz and A. Catarina Sousa (Eds.): $5^{\circ}$ Congresso do Neolítico peninsular, Estudos and memorias, 8, Centro de Arqueologia da Universidade de Lisboa, Lisboa: 264-272.

McClure, S. 2011. Petrographic and technological analysis of pottery from Bènamer". In Torregrosa, P., F. J. Jover and E. López, dirs., Benàmer (Muro del'Alcoi, Alicante), Mesolíticos y neolíticos en las tierras meridionales valencianas, Valencia: Serie Trabajos Varios del SIP, 112, Diputación Provincial de Valencia, 235-238. 
Mestres, J. 1981/82. “Avançament a l'estudi del jaciment de Les Guixeres de Vilobí”. Pyrenae 17-18: 35-83.

Molina, F., J.A. Cámara and J. A. López Sáez. 2012. “Andalucía”. In Rojo, M. Á., R. Garrido, I. García-Martínez de Lagrán: El neolítico en la Península Ibérica y su contexto europeo, Madrid: 405-462.

Molist, M., O. Vicente and R. Farré. 2008. "Estudi del jaciment neolític de la Caserna de Sant Pau del Camp". Quarhis II 04: 14-24.

Molist, M., J. Bosch, X. Clop, A. Gómez and E. Guerrero. 2009. "Des vases cardiales dans la ville de Barcelone: apports du cite de la Caserna de Sant Pau del Camp sur le Néolitique ancien de la Catalogne". In De Méditerranée et d'ailleurs. Mélanges offerts à Jean Guilaine. Toulouse: Archives d’Écologie Préhistorique, 547-555.

Molist, M. and X. Clop. 2009. "Habitations et habitats au début du Néolithique en Catalogne (5500-3500 av J.C.)”. In Beeching, A. and Sénépart, I.: De la maison au village. L’habitat néolithique dans le sud de la France et le Nord-Oest méditerranéen. Actes de la table Ronde 23-24 mai, 2003. Marseille: 73-88.

Montón, S. and M. Sánchez-Romero. 2008. Engendering Social dynamics: the archaeology of maintenance activities. British Archaeological Report (BAR) International Series 1862. Oxford: Archaeopress.

Morales, J., M. Fontanals, F. X. Oms, and J. M. Vegès. 2010. "La chronologie du Néolithique ancien cardial du nord-est de la Péninsule Ibérique. Datacions, problematique et métodologie". L'Anthropologie 114: 427-444.

Nash, D. J. 2009. Household Archaeology in the Andes. Journal of Archaeological Research $17: 205-261$. 
Olalde, I., D. Reich and C. Lalueza-Fox 2017: "El estudio paleogenético de los individuos de El Prado de Pancorbo". In Alonso-Fernández, C.: Vida y muerte en el asentamiento del Neolítico Antiguo de El Prado (Pancorbo, Burgos). Construyendo el Neolítico en la Península Ibérica. BAR International Series 2876. Oxford: BAR Publishing: 135-144.

Oliva, M., A. Palamó, N. Terrats, X. Carlús, J. López, and A. Rodríguez. 2008. "Las estructuras neolíticas de Can Roqueta (Sabadell, Barcelona)”. In Hernández, M.S., J.A. Soler and J.A. López, IV Congreso del Neolítico Peninsular. Alicante: Museo Arqueológico Provincial de Alicante, 157-167.

Oms, F. X., X. Esteve, J. Mestres, P. Martín and H. Martins. 2014. "La neolitización del nordeste de la península Ibérica: datos radiocarbónicos y culturales de los asentamientos al aire libre del Penedès". Trabajos de Prehistoria, 71 (1): 42-55.

Ortega, L.A., I. Guede, M.C. Zuluaga and A. Alonso Olazábal 2017: “Aplicación de los isótopos del estroncio al estudio de la movilidad y cambio de residencia de los habitantes del yacimiento neolítico de El Prado (Pancorbo, Burgos)". In AlonsoFernández, C.: Vida y muerte en el asentamiento del Neolítico Antiguo de El Prado (Pancorbo, Burgos). Construyendo el Neolítico en la Península Ibérica. BAR International Series 2876. Oxford: BAR Publishing: 145-154.

Pallarés, M., A. Bordas and R. Mora. 1996. "La Font del Ros en el proceso de neolitización de los Pirineos Orientales”. In Balbín, R. and P. Bueno, II Congreso de Arqueología Peninsular, Tomo I: Paleolítico y Epipaleolítico. Zamora: Fundación Rei Afonso Henriques, 311-325.

Pérez Díaz, S. and J.A. López Sáez 2017: “El Neolítico antiguo en la sub-meseta Norte desde una perspectiva paleoambiental: estudio palinológico del yacimiento arqueológico de El Prado (Pancorbo, Burgos)”. In Alonso-Fernández, C.: Vida y muerte en el asentamiento 
del Neolítico Antiguo de El Prado (Pancorbo, Burgos). Construyendo el Neolítico en la Península Ibérica. BAR International Series 2876. Oxford: BAR Publishing: 155-164.

Pessina, A. and V. Tiné. 2008. Archeologia del Neolitico. L'Italia tra VI e IV millennio a.C. Roma: Carocci.

Peña-Chocarro, L., G. Pérez, J. Morales, and J. C. Vera. 2013. "Y llegaron los agricultores. Agricultura y recolección en el occidente del Mediterráneo”. Menga 04: 15-33.

Perrin T., L. Bellot-Gurlet, S. Bonnardin, L. Bouby, C. Bressy, P. Chevillot, F. Convertini, I. Figeuiral, V. Forest, C. Manen, S. Martin, P. Séjalon, É. Thirault, J. Wattez. 2011. “Le Mas de Vignoles X (Nîmes, Gard): un habitat de plein air du Néolithique ancien”, in Sénépart I., T. Perrin, É. Thirault, S. Bonnardin dir. Marges, frontières et transgressions. Actualité de la rechercher, Actes des 8e Rencontres méridionales de Préhistoire récente, Marseille 2008, Archives d'Écologie Préhistorique, Toulouse, 233249.

Perrin, T, C. Manen and P. Séjalon. 2014. Le néolithique ancien de la plaine de Nîmes (Gard, France). Toulouse: Institut National de Recherches Archéologiques Preventives.

Pou, R. and M. Martí. 2005. "Les restes del neolític antic al carrer d’en Xammar (Mataró, Maresme)". Laietania 16: 9-23.

Pou, R., M. Martí, X. Jordana, A. Malgosa and J.F. Gibaja. 2010. “L’enterrament del Neolític antic de la Plaça de la Vila de Madrid (Barcelona). Una estructura funeraria del VIé mil·lenni a.C.”. Quarhis II 06: 94-107. 
Puche, M. and Díez Castillo, A. (2003): “El proceso de la neolitización a través de los espacios domésticos en los yacimientos neolíticos al aire libre”. In Arias, P., Ontañón, R. and García-Moncó, C. (Eds), III Congreso del Neolítico en la península Ibérica: 475-484. Santander.

Radina, F. and L. Sarti. 2002. "Le strutture d'abitato in Fugazzola del Pino". In Pessina, M.A. and V. Tiné, eds: La ceramiche impresse nel Neolitico antico. Italia e Mediterraneo. Studi di Paletnologia. Roma: Istituto Poligrafico e Zeccda dello Stato, vom I: 196-207.

Ramos, M. 2007. “Cortecampo II (Los Arcos) Osaleta (Lorca, Valle de Yerri)”. In Hurtado, M.A., F. Cañada, J. Sesma and García, J: La Tierra te sea leve. Arqueología de la muerte en Navarra. Pamplona: 93-96.

Ramos, J., V. Castañeda, M. Pérez, E. Vijande, and A. Castañeda. 2006a. "Embarcadero del río Palmones. Síntesis socioeconómica y perspectivas de investigación”. Almoraima 33: 95-105.

Ramos, J., V. Castañeda, M. Pérez, E. Vijande, and J.J. Cantillo. 2006b. "Las sociedades neolíticas en la banda atlántica de Cádiz. Valoración del contexto regional y del proceso histórico de la formación social tribal. Quaderns de Prehistòria i Arqueologia de Castelló 25: 53-89.

Robb, J. 2007. The Early Mediterranean Village: Agency, Material Culture, and Social Change in Neolithic Italy. Cambridge: Cambridge University Press.

Rojo, M.A., M. Kunst, R. Garrido, I. García and G. Morán. 2008. Paisajes de la memoria: asentamientos del neolítico antiguo en el valle de Ambrona (Soria-España). Instituto Arqueológico Alemán. Valladolid: Universidad de Valladolid. 
Rojo, M., R. Garrido, J.A. Bellver, A. Bravo, I. García, S. Gámez and C. Tejedor. 2010. Zafrín. Un asentamiento del neolítico antiguo en las islas Chafarinas (Norte de África, España). Studia Archaeologica, 96. Valladolid: Universidad de Valladolid.

Rojo, M., R. Garrido, J.A. and I. García. 2012. El Neolítico en la Península Ibérica y su contexto europeo. Madrid: Cátedra.

Rojo, M. A., C. Tejedor, L. Peña-Chocarro, J.I. Royo García, H. Arcusa, M. San Millán, R. Garrido, J.F. Gibaja, N. Mazzuco, I. Clemente, M. Mozota, X. Terradas, M. Moreno, G. Pérez, E. Álvarez, I. Jiménez and F. Gómez. 2015. "Releyendo el fenómeno de la neolitización en el Bajo Aragón a la luz de la excavación del Cingle de Valmayor XI (Mequinenza, Zaragoza)". Zephyrus, LXXV: 41-71.

Rojo, M.A., I. García-Martínez de Lagrán, R. Garrido, C. Tejedor , M. E. Subirà, J. García , J. Sesma, J. F. Gibaja, M. Unzu, A. L. Palomino, I. Jiménez, E. Arroyo and H. Arcusa. 2016. "Enterramientos del neolítico antiguo en el interior peninsular: nuevos datos para una actualización de la evidencia empírica". In Bonet, H.: Del neolític a l'edat de bronze en el Mediterrani occidental: Estudis en homenatge a Bernat Martí Oliver: Valencia. Diputación de Valencia: 180-210.

Rosser, P. and S. Soler. 2016. "Propuesta de fases cronológicas para el asentamiento neolítico del Tossal de les Basses (Alicante, España)". Del neolític a l'edat del bronze en el Mediterrani occidental. Estudis en homenatge a Bernat Martí Oliver. Serie de Trabajos Varios, 119. Servicio de Investigación Prehistórica del Museo de Prehistoria de Valencia. Valencia: Diputación Provincial de Valencia, 225-248.

Schiffer, M. B. 1985: "Is there a "Pompeii Premise" in Archaeology? Journal of Anthropological Research, 41, 1, 18-41. 
Sénépart, I. 2003. "Les structures empierrées de Baratin (Courthézon, Vaucluse): bilan descriptif". In Frère-Sautot, M. C., Le feu domestique et ses structures au Néolithique et à l'Age des Métaux. Actes du colloque de Beaune et Bourg-en-Bresse, 7-8 octobre 2000. Collection Préhistoire 9. Montagnac: Mergoil, M., 231-244.

Sénépart, I. 2009. "L’habitat néolithique ancient cardial du Baratin à Courthézon (Vaucluse)". De le maison au Village. L'habitat néolithique dans le sud de la France et le Nordouest méditerránean. Actes de la table-ronde de la Société Préhistorique Française (Marseille, Mai 2003), Mémoire XLVIII, 61-72.

Sesma, J. 2007. “Los enterramientos neolíticos del yacimiento de Paternanbidea (Ibero)". In Hurtado, M.A., F. Cañada, J. Sesma and García, J: La Tierra te sea leve. Arqueología de la muerte en Navarra. Pamplona: 59-65.

Soares, J., N. Mazzuco and I. Clemente-Conte. 2016. "The first farming communities in the Southwest European Coast: a traceological approach to the lithic assemblage of Vale Pincel I". Journal of Anthropological Archaeology 41: 246-262.

Soler, J. A., D. Duque, C. Ferrer, O. Gómez, P. M. Guillem, P. Iborra, R. Martínez, G. Pérez, C. Roca de Togores and T. Ximénez de Embún. 2013. "Sobre el significado de la primera ocupación neolítica de la Cova d'en Pardo (Planes, Alicante): avance de estudio pluridisciplinar de los niveles VIII y VIIIb”. Saguntum 45, 9-24.

Souvatzi, S. G. 2007. "The identification of Neolithic households: unfeasible or just disregarded?”. In Westgate, R., N. Fisher and J. Whitley, Building communities: House, Settlement and Society in the Aegean and Beyond, British School at Athens Studies 15. Athens: British School at Athens, 19-28. 
Souvatzi, S.G. 2008. A social archaeology of households in Neolithic Greece. An anthropological approach. Cambridge: Cambridge University Press.

Stevanović, M. 1997. "The age of clay: the social dynamics of house destruction". Journal of Anthropological Archaeology, 16: 334-395.

Suárez, J. and J. A. Márquez. 2014. "La problemática de los fondos de cabaña en el marco de la Protohistoria del sur de la península ibérica". Menga 05: 199-225.

Szécsényi-Nagy, A., C. Roth, G. Brandt, C. Rihuete-Herrada, C. Tejedor-Rodríguez, P. Held, Í. García-Martínez-de-Lagrán, H. Arcusa Magallón, S. Zesch, C. Knipper, E. Bány, S. Friederich, H. Meller, P. Bueno Ramírez, R. Barroso Bermejo, R. de Balbín Behrmann, A. M. Herrero-Corral, R. Flores Fernández, C. Alonso Fernández, J. Jiménez Echevarria, L. Rindlisbacher, C. Oliart, M.-I. Fregeiro, I. Soriano, O. Vicente, R. Micó, V. Lull, J. Soler Díaz, J. A. López Padilla, C. Roca de Togores Muñoz, M. S. Hernández Pérez, F. J. Jover Maestre, J. Lomba Maurandi, A. Avilés Fernández, K. T. Lillios, A. Maria Silva, M. Magalhães Ramalho, L. Miguel Oosterbeek, Cl. Cunha, A. J. Waterman, J. Roig Buxó, A. Martínez, J. Ponce Martínez, M. Hunt Ortiz, J. C. MejíasGarcía, J. C. Pecero Espín, R. Cruz-Auñón Briones, T. Tomé, E. Carmona Ballestero, J. Luís Cardoso, A. Cristina Araújo, C. Liesau von Lettow-Vorbeck, C. Blasco Bosqued, P. Ríos Mendoza, A. Pujante, J. I. Royo-Guillén, M. A. Esquembre Bevia, V. M. Dos Santos Goncalves, R. Parreira, E. Morán Hernández, E. Méndez Izquierdo, J. Vega y Miguel, R. Menduiña García, V. Martínez Calvo, O. López Jiménez, J. Krause, S. L. Pichler, R. Garrido-Pena, M. Kunst, R. Risch, M. A. Rojo-Guerra, W. Haak, K. W. Alt 2017: "The Maternal genetic make-up of the Iberian Peninsula between Neolithic and Early Bronze Age”. Scientifics reports, 7: 15644. DOI:10.1038/s41598-017-15480-9 
Tavares da Silva, C and J. Soares. 2015. "Neolitizaçao da costa sudoeste portuguesa. A cronologia de Vale Pincel I”. In Gonçalves V., M. Diniz and A. Sousa (eds). Actas do $5^{\circ}$ Congresso do Neolitico Peninsular. Centro de Arqueologia da Universidade de Lisboa. Lisboa: 645-659.

Terradas, X., R. Mora, C. Plana, A. Paipal and J. Martínez. 1992. "Estudio preliminar de las ocupaciones del yacimiento al aire libre de la Font del Ros (Berga, Barcelona)”. In Utrilla, P., Aragón. Litoral Mediterráneo. Intercambios culturales durante la Prehistoria. Zaragoza: Diputación de Zaragoza, 285-296.

Torregrosa, P. 2000. La pintura rupestre esquemática en el levante de la Península Ibérica, Tesis doctoral, Universidad de Alicante. http://rua.ua.es/dspace/handle/10045/4080

Torregrosa, P., F. J. Jover and E. López. 2011. Benàmer (Muro d'Alcoi, Alicante). Mesolíticos y neolíticos en las tierras meridionales valencianas. Serie de Trabajos Varios 112. Servicio de Investigación Prehistórica del Museo de Prehistoria de Valencia. Valencia: Diputación Provincial de Valencia.

Vaquer, J., J.P. Giraud, S. Bazalgues and M. Gandelin 2003: "Les structures à pierres chauffées du Néolithique dans le Sudoest de la France”. In Mergoil, M., Le fue domestique et ses structure au néolithique et aux âges des Métaux. Actes du Colloque de Bourg-en-Bresse et Beaune. Montagnac: 21-35.

Veloz, M. 1984. "La arqueología de la vida cotidiana: matices, historia y diferencias". Boletín de Antropología Americana 10: 5-22.

Whittle, A. 2012. "El Neolítico en Europa. Cuestión de escala y tempo". In Rojo, M.A., R. Garrido, and I. Martínez de Lagrán, El Neolítico en la península Ibérica y su contexto europeo. Madrid: Cátedra, 13-26. 
Wilk, R. R. and W. L. Rathje. 1982. "Household archaeology". American Behavioral Scientist 24 6: 617-639.

Wilk, R.R., and R. McC. Netting. 1984. Households: changing forms and functions. In Households: comparative and historial studies of the domestic group, ed by R. McC. Netting, R. Wilk and E. Arnould, Berkeley and Los Angeles: University of California Press: $1-28$.

Yasur-Landau, A., J. R. Ebeling, and L. B. Mazow. 2011. Household Archaeology in Ancient Israel and Beyond. Leiden: Brill.

Zapata, L., L. Peña-Chocarro, G. Pérez and H. P. Stika. 2004. "Early neolithic agriculture in Iberian Peninsula”. Journal of Word Prehistory 18: 283-325.

Zilhão, J. 2011. "Time is on my side..." In A. Hadjikounis, A. Robinson and S. Viner, The dynamics of neolithisation in Europe. Oxford: Oxbow Books, 46-65. 